\title{
Coastal Evolution Over the Past 3000 Years at Conrads Beach, Nova Scotia: the Influence of Local Sediment Supply on a Paraglacial Transgressive System
}

\author{
Tanya C. Forde ${ }^{1} \cdot$ Mladen R. Nedimović $^{1} \cdot$ Martin R. Gibling $^{1} \cdot$ Donald L. Forbes $^{1}$
}

Received: 23 September 2014 / Revised: 9 July 2015 / Accepted: 16 July 2015 /Published online: 4 September 2015

(C) The Author(s) 2015. This article is published with open access at Springerlink.com

\begin{abstract}
Many coastlines are retreating in response to sea level rise, compounded by glacial-isostatic subsidence in areas marginal to former ice sheets. The resulting barrier and estuarine deposits are dominated by transgressive stratigraphy. Where supplied primarily from relict glacial deposits, this "paraglacial" sediment input may rise and fall, increasing as a new source such as a drumlin headland is exposed to erosion but declining as the source becomes exhausted. Conrads Beach, on the Atlantic coast of Canada, has experienced a succession of barrier growth and reworking as sediment supply from several drumlin sources has varied over the past 3000 years. In the context of long-term regional transgression, there have been intervals of years to centuries characterized by local stability or progradation. Ground-penetrating radar profiles and refraction seismic data were used to image the facies architecture of Conrads Beach to depths of 6-8 and 10-24 m, respectively. Thirteen vibracores provided a record of lithofacies characteristics and geometry. Results show evidence of an estuarine basin at $\sim 2800$ years BP. As the outer coast retreated, erosion of drumlins provided multi-century sediment pulses to adjacent beaches and embayments. Locally increased sediment supply fed a prograding beach ridge complex from $>600$ to $\sim 150$ years $\mathrm{BP}$ and tidal channels feeding sediment to back-barrier flood delta deposits. This study documents the complexity of coastal adjustment to time- and source-varying sediment supply under long-term rising sea level. It expands and refines previous models,
\end{abstract}

Communicated by Scott C. Neubauer

Tanya C. Forde tn698068@dal.ca

1 Department of Earth Sciences, Dalhousie University, Room 3006, Life Sciences Centre, Halifax, Nova Scotia B3H 4R2, Canada providing guidance required for effective management and hazard mitigation on transgressive paraglacial coasts.

Keywords Atlantic Canada - Sea level rise · Paraglacial · Barrier beach · Dune $\cdot$ Beach ridges $\cdot$ Tidal inlet . Ground-penetrating radar $\cdot$ Refraction seismic $\cdot$ Lithofacies

\section{Introduction}

Barrier islands and coastal dune systems are distributed globally under a variety of climates and form vital, dynamic buffers that protect coastlines from high-water events (Carter 1988; Martinez et al. 2008). Sediments are supplied to coastal systems by the reworking of seafloor deposits, by longshore sediment transport, and by rivers. Marine processes play an important role in shaping coastal landforms through the dynamic interplay between geomorphic setting, climate, hydrodynamics, sediment transport, and biogeochemistry (Reed et al. 2009). In the case of established coastal dunes, factors that influence their morphological development include sand supply, sand remobilization, vegetation cover, intensity of wind and wave forces, frequency and magnitude of storms and overwash, long-term beach state, water levels, and human impacts (Hesp 2002; Davidson-Arnott 2010). Rising sea level affects storm water levels, nearshore wave dynamics, and overwash events, thus directly affecting the shore zone system and indirectly affecting coastal dunes and ecosystems (McCann 1990; Brown and McLachlan 2002; Woodroffe et al. 2014).

The Atlantic coast of Nova Scotia has experienced a rapid rate of Holocene relative sea level change, with an average rise of $2 \mathrm{~m}$ every 1000 years for the past 2000 years and more rapidly before that (Forbes et al. 1991a; Shaw et al. 1993; Scott et al. 1995; Gehrels et al. 2004). The tide gauge record 
at Halifax indicates a mean rate of $3.2 \pm 0.1 \mathrm{~mm} /$ year for relative sea level rise over the past century (Shaw et al. 1993; Forbes et al. 2009), approximately double the rate before AD 1900 (Gehrels et al. 2005). Rising sea levels and storm impacts together have led to retreating headlands and beaches, dune erosion, and infilling of estuaries along this coast (Scott 1980; Forbes et al. 1990, 1991b, 1997; Shaw et al. 1993). Shaw et al. (1998) used a set of criteria to rank the sensitivity of Canada's coastline to sea level rise. They concluded that the presence of low-relief, unlithified glaciogenic sediments, beaches, barriers, salt marshes, and peat, and a high rate of sea level change contribute to Atlantic Canada's moderate and high coastal sensitivity.

The response of coastal areas to Holocene sea level rise has been documented at several key sites along the Atlantic coast of Nova Scotia (e.g., Taylor et al. 1985, 1996, 2014; Boyd et al. 1987; Carter et al. 1989; Forbes et al. 1989, 1990, 1991b, 1997; Boyd and Honig 1992; Nichol and Boyd 1993; Shaw et al. 1993). At Conrads Beach and Lawrencetown Beach, $25 \mathrm{~km}$ east of Halifax (Fig. 1a, b), geomorphic changes on the scale of decades to millennia have been documented by several workers (Hoskin 1983; Boyd et al. 1987; Nichol and Boyd 1993; Shaw et al. 1993), along with shorter term and storm-specific adjustments to beach profiles (Taylor et al. 1985, 1996), dune morphology (Hales 1992), and the late Holocene history of Lawrencetown Lake (Boyd and Honig 1992). The evolutionary model for coastal barriers on a transgressive drumlin coast, first published by Boyd et al. (1987) (see also Forbes and Taylor 1987) and refined over the following decade (e.g., Carter et al. 1987, 1989, 1990; Carter and Orford 1988; Forbes et al. 1989, 1990, 1995a, b, 1997; Nichol and Boyd 1993; Shaw et al. 1993; Orford et al. 1995, 1996, 2000), came to be recognized as the "Eastern Shore" model of paraglacial coastal evolution (Forbes and Syvitski 1994; Forbes 2005, 2011). At the same time, the nature and distribution of gravel and sand barrier facies and the processes of estuarine sedimentation have been illuminated by a number of coring projects (e.g. Carter et al. 1992; Boyd and Honig 1992; Nichol and Boyd 1993; Jennings et al. 1993). This has provided a strong conceptual framework for analysis of coastal change in the region, but many details of the evolution of gravel barriers, the conditions favoring formation of sandy barrier systems, the response to waning sediment supply, and the opening and closing of tidal inlets remain poorly understood (Forbes 2011) and may be clarified by more detailed local studies.

This paper addresses the questions raised above through a focused study of beach and dune characteristics and evolution in relation to local sediment supply at Conrads Beach. Using a range of techniques to map the planform evolution, facies characteristics, three-dimensional architecture, and chronology of the sediments accumulated in this system, this study advances understanding of the complex patterns of response to sea level rise, headland erosion, and varying local sediment supply at a representative site on the Eastern Shore of Nova Scotia. We extend previous research results by acquiring highresolution surface and subsurface data from maps and aerial images, a lidar (light detection and ranging) digital elevation model, ground-penetrating radar (GPR) profiles, seismic refraction data, and coring to enable lithofacies analysis and radiocarbon dating of the deposits. We establish a robust understanding of coastal sediment accumulation in this area over the past 3000 years, clarifying the details of stage transitions in the Eastern Shore drumlin coast model (Boyd et al. 1987). Thus, the results of this study not only are relevant to coastal management policy in the study region but may also enhance the value of the Eastern Shore model in applications to other paraglacial coastal systems (e.g., Carter and Orford 1988; Carter et al. 1989; Forbes and Syvitski 1994; FitzGerald and van Heteren 1999; Orford et al. 2000; Himmelstoss et al. 2006; Greenwood and Orford 2007).

\section{Field Site and Geological Background}

Conrads Beach is located on the Atlantic coast of Nova Scotia, along the Eastern Shore, $25 \mathrm{~km}$ east of Halifax (Fig. 1a, b). The study site has $2.7 \mathrm{~km}$ of shoreline and an area of $\sim 1.4 \mathrm{~km}^{2}$. It lies within a coastal sediment compartment stretching from Conrod Head east past Lawrencetown Head to Half Island Point (Fig. 1b) and comprises several coastal cells delimited by intermediate headlands and shoals, where the latter represent the non-eroded remnants or planed-off bases of glacial drumlins (Taylor et al. 1996). This study focuses on the subcompartments between Conrod Head and Lawrencetown Head, with a complex coastal barrier system, beach ridges, dunes, and tidal inlets (Figs. 1c and 2). The region is underlain by metasedimentary rocks (greywackes and slates) of the Cambrian-Ordovician Goldenville and Halifax groups (White 2010), with very limited relief resulting from long-term peneplanation (King 1972). While rock locally anchors coastal systems, the most prominent headlands are drumlins. These are typically less than $15 \mathrm{~m}$ high and are cut by coastal cliffs exposing three distinctive glacial tills (Stea and Brown 1989; Stea et al. 1998); low areas between the drumlins have thinner till $<10 \mathrm{~m}$ thick (Forbes et al. 1991a; Utting 2011). Eroding drumlin headlands are present both west and east of Conrads Beach (Conrod Head and Lawrencetown Head, respectively; Fig. 1c). Beach sediment is predominantly sand with a pebble-cobble storm ridge or cobble berm at the western end and in the lee of the Fox Island tombolo (west side of Fox Point). The sediment is derived in part from Conrod Head, with the depleted Egg IslandFox Island drumlin complex providing an important sediment source in the past (Boyd et al. 1987; Taylor et al. 1996; Forbes 2011). Some sediment may be recycled from former beach 
A

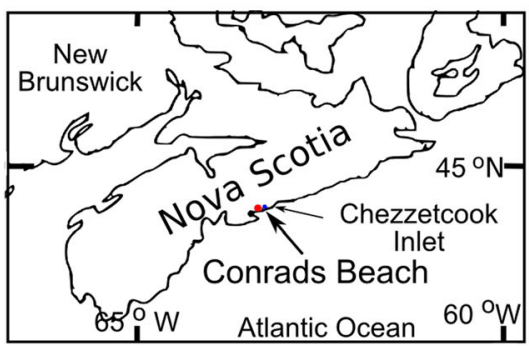

C

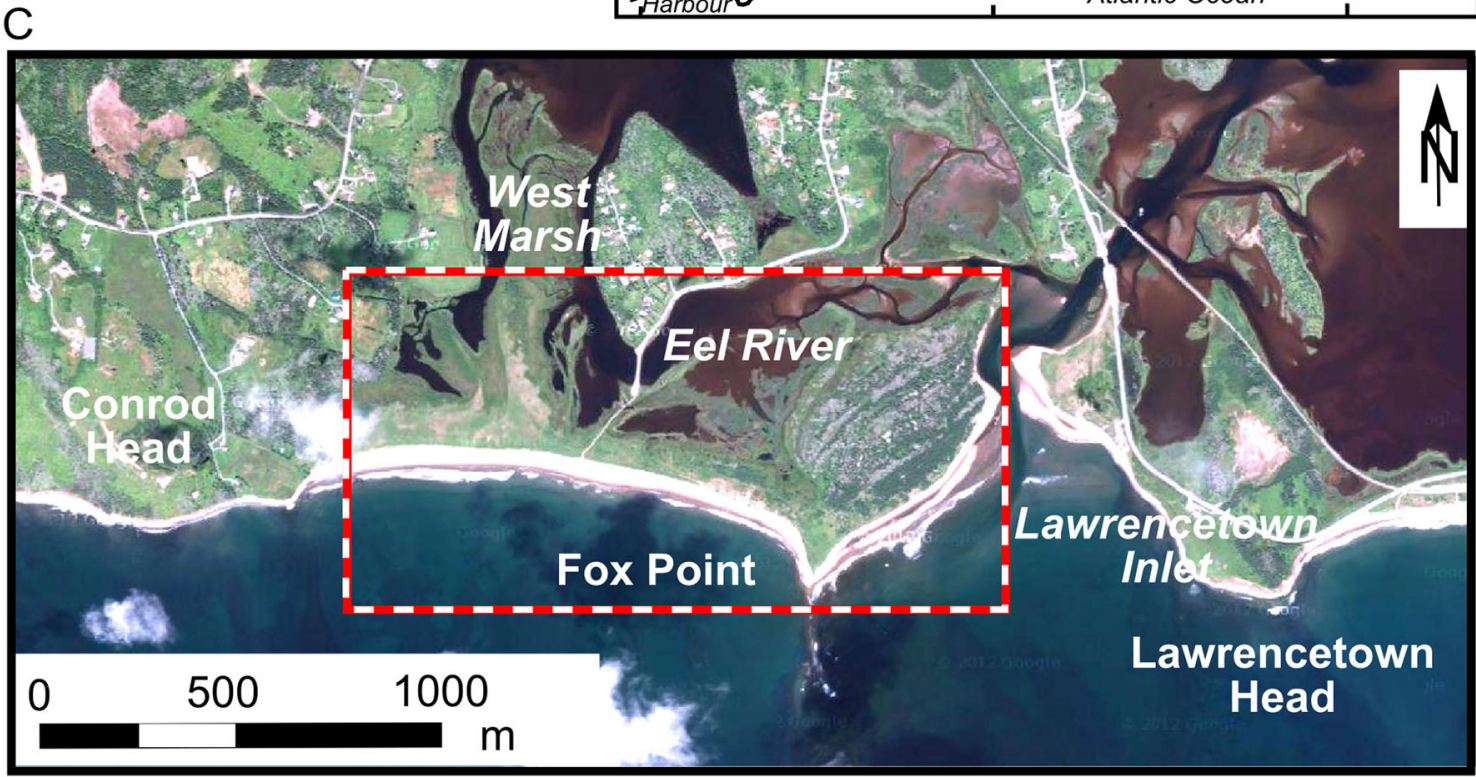

Fig. 1 Study area. a Atlantic Canada. b Eastern Shore of Nova Scotia, Canada. CH, LH, and HIP are Conrod Head, Lawrencetown Head, and Half Island Point, respectively. c Satellite image showing Conrod Head to Lawrencetown Head. The dashed rectangle shows the location of Fig. 2

deposits on the shoreface, and some may have originated as estuarine infill at a time when the open coast was further seaward (Boyd et al. 1987; Forbes et al. 1990). East of Fox Point, the Lawrencetown Inlet ebb shoal contains a large volume of sand immediately seaward of the sandy beach ridge complex at the eastern end of Conrads Beach (Fig. 1c). A gravel storm ridge is located east of the inlet on the western flank of Lawrencetown Head.

Conrads Beach has several geomorphic components (Fig. 2a). There is a sandy beach, which varies in width from 12 to $85 \mathrm{~m}$, measured from the seaward edge of the dunes to the water line in the 2012 satellite image (the mean width varies substantially with the tides and the seasons). West of Fox Point, the beach passes gradually landward into dunes with crests $2-3 \mathrm{~m}$ above mean sea level. Behind the beach east of the point, the dunes are up to $5 \mathrm{~m}$ high and cut by a steep backshore scarp. The dunes are vegetated, predominantly with marram grass (Ammophila breviligulata). The landward margins support saltmarsh vegetation bordering the lagoonal areas of West Marsh and Eel River. A large area of beach ridges with undulating topography and extensive tree cover, primarily spruce (Picea sp.), lies north and east of Fox Point (because of the aeolian sand cover, these are technically dune ridges, but they formed by beach progradation and are referred to as beach ridges in this paper).

Anthropogenic activities since European settlement are well documented. Human impacts, including grazing, grass harvesting, uncontrolled vehicular access, and now-prohibited sand and gravel extraction, have affected the stability of many beaches and barriers in this region (Taylor et al. 1985, 1996). In 1984, the study area received protected beach status (Bird 1984) and active management since then has effected some recovery from the negative impacts of activities listed above.

The Labrador Current flows southwest along the Atlantic Coast of Nova Scotia, with ocean surface temperatures in the range of $15-18{ }^{\circ} \mathrm{C}$ in the summer and $0-3{ }^{\circ} \mathrm{C}$ in the winter (Phillips 1990). During the 
Fig. 2 Study site. a Conrads Beach showing locations of GPR traverses, vibracores, and midpoints of shallow seismic refraction spreads superimposed on the mapped geomorphological units. The radargram sections of GPR traverses 2, 36, 59, 68, and 6 (Fig. 4) are indicated by thick gray lines. b Shaded-relief image from 2008 lidar digital elevation model. Elevation profiles were taken along transects $\mathbf{a}, \mathbf{b}$, and $\mathbf{c}$
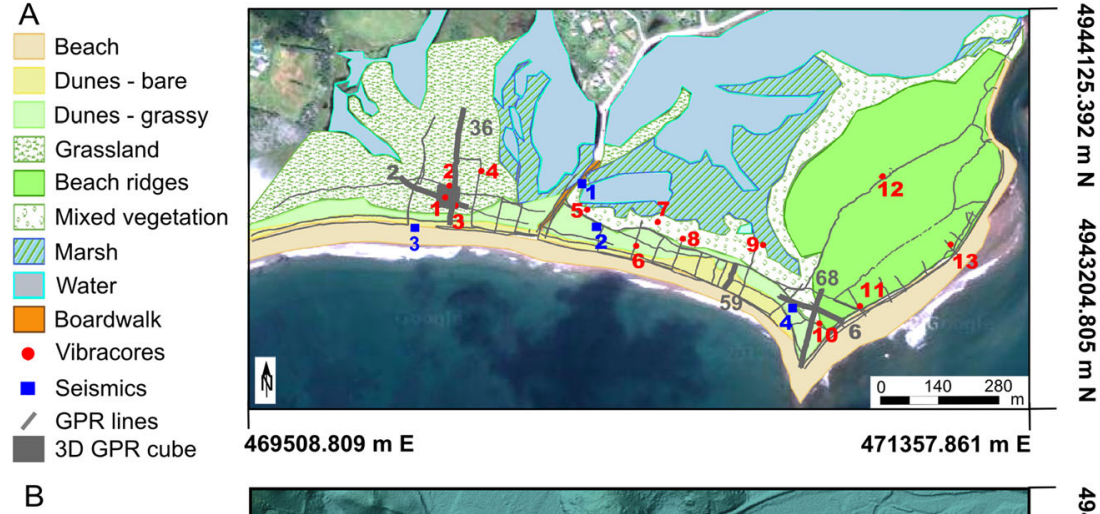

- Vibracores
Transects

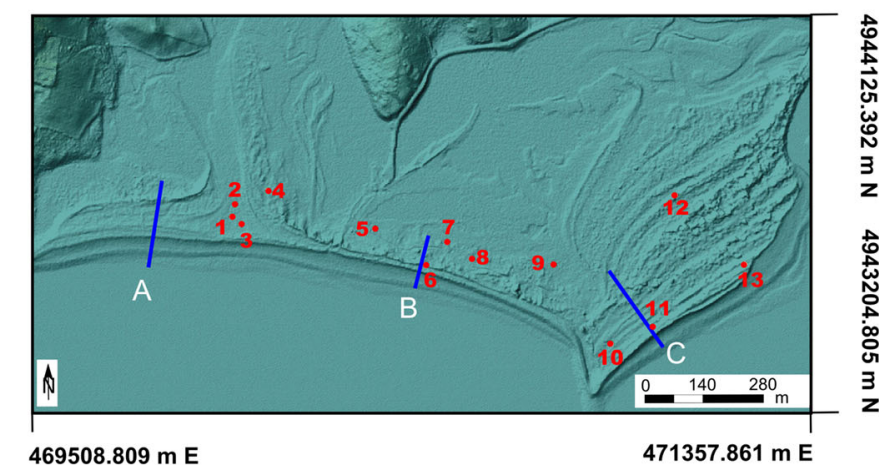

Lawrencetown Lake estuaries are tidal but have minimal fluvial input.

\section{Methods and Data}

Figure 2 shows the locations of field data used in this study. GPR positioned with a differential Global Positioning System (GPS) was the main method used for imaging the subsurface (Fig. 2a). GPR has been used to image coastal dunes worldwide (Bristow et al. 2000; Neal and Roberts 2001; GonzálezVillanueva et al. 2011). Seismic data (Fig. 2a) were collected to determine the thickness of the unlithified sediments, which could not be resolved using the GPR due to the latter's depth penetration limitations. Vibracoring, at locations selected on the basis of the GPR profiles (Fig. 2a, b), provided samples for grain size analysis and radiocarbon dating. Additional surface and elevation data were obtained from aerial photographs, satellite images, ground surveys, maps, and a digital elevation model derived from airborne scanning laser altimetry (lidar) data (Fig. 2b).

The lidar data were acquired in 2008 by the Halifax Regional Municipality in partnership with the Geological Survey of Canada and the Province of Nova Scotia (Forbes et al. 2009). The data made available for this project were from a "bare-Earth" (buildings and vegetation removed) digital elevation model (DEM), adjusted to the Canadian Geodetic Vertical Datum 1928 (CGVD28), with a vertical resolution of $\pm 15 \mathrm{~cm}$, gridded horizontally at $2 \mathrm{~m}$ (Fig. 2b). Lidar- 


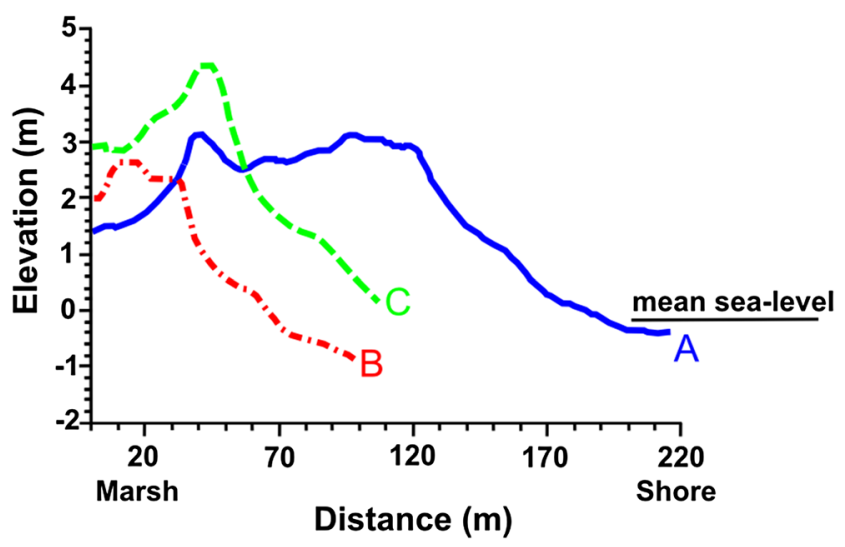

Fig. 3 Cross-shore elevation profiles at three locations. The profiles are derived from the 2008 lidar digital elevation model (Fig. 2b)

derived profiles (Fig. 3) are consistent with observations made during site visits.

\section{Positioning and Elevation}

A Leica Geosystems GPS $1200^{\mathrm{TM}}$ was used in real-time kinematic mode with the GPR system to collect location and elevation data with a precision of $\pm 1.5 \mathrm{~cm}$. Core locations were also surveyed with this system. To maintain positional accuracy, the GPS base station receiver for each survey was centered over a fixed reference point (Taylor et al. 1996). The Universal Transverse Mercator (UTM) Zone 20 North coordinate system was used with the World Geodetic System (WGS) 1984 ellipsoidal datum.

To plot the elevations of our cores and samples relative to a sea level curve derived from paleoecological data referenced to higher high water at large tides (HHWLT), it was necessary to determine the difference between HHWLT, CGVD28, and the ellipsoidal elevations derived from the GPS. The ellipsoidal datum is $19.6 \mathrm{~m}$ above CGVD28 in this region (this accounts for negative elevations in some figure axes). Because mean relative sea level has been rising over the past century, it is now about $27 \mathrm{~cm}$ above CGVD28. The elevation of HHWLT at Chezzetcook was determined to be $1.14 \mathrm{~m}$ in 1964 (P. MacAulay, pers. comm., 2014), and sea level has risen about $15.4 \mathrm{~cm}$ since that time, so that HHWLT today is about $1.29 \mathrm{~m}$ above CGVD28 in that area. This allows us to obtain the elevations of our samples, determined using GPS, relative to HHWLT at Chezzetcook.

\section{Geophysical Surveys}

A Sensors and Software Inc. Smart Cart ${ }^{\mathrm{TM}}$ GPR system with 50,100 , and $200 \mathrm{MHz}$ antennas was used to collect common offset GPR traverses. Common mid-point (CMP) vertical profiles were also collected at a frequency of $200 \mathrm{MHz}$ and a step size of $0.2 \mathrm{~m}$. A total of 182 common offset traverses amounting to $20.3 \mathrm{~km}$ were acquired, mainly parallel or perpendicular to the shoreline (Fig. 2a) and with near-zero common offset $(0.5 \mathrm{~m})$. Reconnaissance traverses acquired in 2010 intersected a buried channel south of West Marsh.

The GPR data were processed using Sensors and Software EKKO_View Deluxe and Paradigm Focus software. The dewow high-pass filter was applied to remove the inductive low-frequency component of the GPR data (Sensors and Software Inc. 2006), followed by application of a trapezoid bandpass filter. Precise elevation information was required to apply a topographic correction to the GPR data. The GPS rover occasionally lost contact with the base station and, in the case of six traverses, the vertical position was computed by interpolation. These GPS files were edited manually prior to topographic correction. All GPR traverses were migrated using a velocity of $0.125 \mathrm{~m} / \mathrm{ns}$. A top-mute was applied to remove migration noise arriving prior to the direct wave. ArcGIS 9.2 was used for GPS data visualization and Kingdom Suite 8.6 and OpendTect 4.4.0 were used for GPR/GPS data visualization.

Refraction seismic data were collected using the Geode/ ES-3000 Seismic System ${ }^{\text {TM }}$. At each location (Fig. 2a), two spreads with 24 vertical geophones were spaced 5 and $1 \mathrm{~m}$ apart and planted on the surface. A long $120 \mathrm{~m}$ spread was used to determine the thickness and velocity of sediment and the velocity of the crystalline bedrock basement. A short $24 \mathrm{~m}$ spread was used to determine the thickness and velocity of the uppermost layer of surficial material characterized by slow Pwave velocity. The source for the long spread was a buffalo shotgun (12-gauge steel shot) triggered at 0.5-1 $\mathrm{m}$ depth to generate a strong signal with deep penetration. For the short spread, a sledgehammer was struck at the surface to generate refractions at the shallow boundary between the sediment layers characterized by slow and fast P-wave velocities. Head waves at this boundary could not be generated using the shotgun source, which is triggered below this interface. The shotgun and sledgehammer were triggered at both ends of the spreads, 5 and $1 \mathrm{~m}$ from the last geophone, respectively. To improve the signal-to-noise ratio, shot gathers for both shotgun and sledgehammer source were formed by stacking 5 and 30 records, respectively.

Data analysis used Refract software (Burger et al. 2006), following the method of Aadachi (1954). First arrivals, picked on amplitude-balanced and bandpass-filtered shot gathers, were input into the software, and a starting subsurface model was formed, constrained by the picked first arrivals and containing an arbitrary number of layers separated by planar interfaces. These initial conditions allow Refract software to calculate the first arrival times for the starting model and to adjust the subsurface model to minimize the root mean square misfit between the modeled and the picked travel times. 


\section{Coring and Sediment Analysis}

Vibracoring was carried out following GPR data analysis, which identified many potential subsurface targets. Vibracore locations were selected to represent beach, dune, marsh, and tidal channel depositional environments. A Wink Vibracore System ${ }^{\mathrm{TM}}$ was employed at 13 locations (Fig. 2) for which the elevation was determined using the differential GPS. The cores were collected using aluminum pipes $5 \mathrm{~m}$ in length and $10 \mathrm{~cm}$ in diameter, with $5 \mathrm{~mm}$ wall thickness. Core compaction was measured prior to retrieval and corrected using a linear stretch. The cores were split longitudinally, yielding an archive half and a working half. Each working segment was photographed in color and sketched on core $\log$ sheets at a scale of 1:5. Cores were described, noting sediment texture (grain size and shape), sedimentary structures, fossil material, and Munsell color.

Grain size analysis was carried out using standard methods. The samples were wet-washed through a $63-\mu \mathrm{m}$ filter to determine the mud fraction. The mud was discarded from sandrich samples containing less than $2 \%$ mud. Organic material in the mud-rich samples was removed using a $35 \%$ hydrogen peroxide solution. The gravel and sand fractions were sieved at $1 / 4 \phi$ intervals to measure and separate the gravel. Finer material (less than $1.0 \phi$ or $2 \mathrm{~mm}$ ) was analyzed using a Beckman Coulter LS230 Laser Diffraction AnalyzerTM. The weighted percentages of gravel, sand, and mud were entered into GRADISTAT software (Blott and Pye 2001), and the sample statistics were calculated using the method of moments (Krumbein and Pettijohn 1938; Folk and Ward 1957).

\section{Radiocarbon Dating}

Woody material, shell fragments, and peat were removed from cores using tweezers. After being air-dried and weighed, seven samples were submitted to BETA Analytic Inc. for ${ }^{14} \mathrm{C}$ dating using accelerator mass spectrometry. The shell fragments were pretreated using acid etching. Woody samples and plant material extracted from peat were pretreated using a standard acid/alkali/acid method. INTCAL13 and MARINE13 databases were used to calibrate the radiocarbon ages (Reimer et al. 2013).

\section{Analysis of Shoreline Change}

The historical record of shoreline change at Conrads Beach was examined by analyzing historical maps, vertical aerial photographs, satellite imagery, and lidar data (Table 1, Figs. 2 and 3). Sections of the 1865 map were photographed with a 9-megapixel digital camera, and a digital copy of the 1906 map was downloaded from the Geological Survey of Canada website. The 1945, 1954, 1964, 1974, 1992, 1997 , and 2002 air photos were scanned at 800 dpi (ground resolution $0.3-0.5 \mathrm{~m}$ ) and the 1960 and 1973 air photos at 1200 dpi (ground resolution $0.5-0.7 \mathrm{~m}$ ). The 2008 satellite image digital file (ground resolution of $0.3 \mathrm{~m}$ ) was referenced to Universal Transverse Mercator Zone $20 \mathrm{~N}$ in the Canadian Spatial Reference System (NAD83) and covered the largest surface area. The 2010, 2012, and 2013 satellite images were obtained from Google Maps Imagery (Table 1). The 2008 satellite image was converted to WGS 1984 in ArcGIS, and then it and three ground reference points were used to georectify the other maps (except for maps with an areal extent too small for georectification) and photographs. Table 1 gives the total root mean square (RMS) error for each georectified image in map units. To calculate errors for retreat rates of vegetation lines along the seaward dune edge, the RMS errors for selected images were squared, the values were added, and the square root was divided by the number of years between the images. The georectified images and lidar and GPS field data were displayed in ArcGIS. This allowed the areal extent of the different geomorphic elements (e.g., beach, dune, marsh) and the vegetation line along the dunes to be compared from image to image.

\section{Results}

\section{GPR and Seismic Results}

The GPR $100 \mathrm{MHz}$ antennas provided useful images of the subsurface to depths of 6-8 $\mathrm{m}$, estimated using an average near-surface velocity of $0.11 \mathrm{~m} / \mathrm{ns}$ from the CMP surveys. Using this velocity, the depth resolution was $\sim 0.3 \mathrm{~m}$ (based on the quarter of the dominant wavelength rule: Widess 1973; Annan 2009), and the lateral resolution at a depth of $8 \mathrm{~m}$ was $\sim 2 \mathrm{~m}$ (based on the radius of the first Fresnel zone: Annan 2009). Imaged subsurface reflectors were variably continuous or discontinuous, horizontal, dipping and/or sigmoidal, and chaotic. Four radar facies were identified.

Figure 4 shows sample radargrams with numbered facies, providing a geomorphic context for the radar facies analysis. Elevations are given with respect to the GPS ellipsoidal datum. The bands at the top of the line mirror the topography and represent the ground wave. Line 2 (Fig. 4a) runs just inland from the modern beach in the western part of the study area (Fig. 2a). At greater depth from 42 to $22 \mathrm{~m}$ on the $x$-axis, a $\mathrm{U}$-shaped reflector is bordered by sigmoidal reflectors that dip southeastward from 42 to $90 \mathrm{~m}$ (Fig. 4a). Line 36 (Fig. 4b) is oriented north-south (Fig. 2a) and intersects the same package of U-shaped and sigmoidal reflectors. Line 59 (Fig. 4c), east of the main beach access, runs across the beach toward the marsh (Fig. 2a). It travels up and over a dune at 38-28 m (Fig. 4c, marsh to the left). Line 68 (Fig. 4d) starts near the point at Fox Point and runs northeast (Fig. 2a). Grassy dunes 
Table 1 Photograph, image and map sources

\begin{tabular}{|c|c|c|c|c|}
\hline Date & Material & Scale & Total RMS error & Source \\
\hline 1779 & Map & $1: 80,000$ & N/A & Taylor et al. (1985) \\
\hline 1865 & Map & $1: 11,880$ & 15.6 & Church (1865), Nova Scotia public archives \\
\hline 1906 & Map & $1: 63,360$ & 26.4 & Faribault (1906) \\
\hline July 1945 & Air photo & $1: 15,000$ & 4.04 & National Air Photo Library \\
\hline 1951 & Map & $1: 80,000$ & N/A & Taylor et al. (1985) \\
\hline 1954 & Map & $1: 60,000$ & N/A & Taylor et al. (1985) \\
\hline July 1954 & Air photo & $1: 15,840$ & 5.55 & National Air Photo Library \\
\hline 1960 & Air photo & $1: 25,400$ & 3.55 & National Air Photo Library \\
\hline 1973 & Air photo & $1: 33,000$ & 5.10 & Nova Scotia Land Registry Service \\
\hline August 11, 1974 & Air photo & $1: 10,880$ & 5.40 & Nova Scotia Land Registry Service \\
\hline 1974 & Map & $1: 60,000$ & N/A & Taylor et al. (1985) \\
\hline 1981 & Map & $1: 10,000$ & N/A & Taylor et al. (1985) \\
\hline July 25, 1992 & Air photo & $1: 10,000$ & 3.75 & Nova Scotia provincial photos \\
\hline October 25, 1997 & Air photo & $1: 10,000$ & 5.45 & Nova Scotia provincial photos \\
\hline August 2002 & Air photo & $1: 10,000$ & 4.54 & Nova Scotia provincial photos \\
\hline October/November 2003 & Digital air photo & $1: 24,000$ & 1.07 & Department of Natural Resources \\
\hline 2008 & Lidar survey & N/A & N/A & Halifax Regional Municipality \\
\hline 2008 & Satellite image & N/A & 1.07 & Halifax Regional Municipality \\
\hline 2010 & Satellite image & $1: 20,000$ & 2.47 & Google Maps Imagery 2010 CNES/SPOT, Digital Globe \\
\hline 2012 & Satellite image & $1: 20,000$ & 1.89 & Google Maps Imagery 2012 CNES/SPOT, Digital Globe \\
\hline 2013 & Satellite image & $1: 20,000$ & 5.35 & Google Maps Imagery 2013 CNES/SPOT, Digital Globe \\
\hline December 2013 & Satellite image & $1: 20,000$ & 2.76 & Google Maps Imagery 2013 CNES/SPOT, Digital Globe \\
\hline
\end{tabular}

near the beginning of the line become mixed vegetation near the middle of the line and beach ridges near the end (left in Fig. 4d). The seaward-dipping, low-angle, sigmoidal reflectors are representative of the beach ridges. Line 6 (Fig. 4e) in the eastern part of the study area crosses vegetated dunes and runs southeastward across vegetated beach ridges (Fig. 2a, b). The sigmoidal, southeastward-dipping reflectors at 125 to $42 \mathrm{~m}$ on the $x$-axis represent seaward-prograding beach ridges (Fig. 2b). From the northwestern end of the line to position $125 \mathrm{~m}$, reflectors that dip approximately northwestward may represent dune flank deposits, seen tangentially.

Radar facies 1 has continuous, planar to sinuous, parallel to subparallel reflections and has a sheet to sheet-drape configuration. This facies includes the air wave/ground wave, which mirrors the topography and generates what appears to be a signal with a wide time interval (on the order of $\sim 1 \mathrm{~m}$ thick). Facies 1 also appears at depth with closely spaced reflectors (on the order of $\sim 0.5 \mathrm{~m}$ thick) (Fig. $4 \mathrm{a}, \mathrm{b}, \mathrm{e}$ ), where it may represent nearly flat-lying strata formed in beaches and lagoon fringes.

Radar facies 2 (Fig. 4a, b) has planar to sigmoidal, dipping, subparallel, moderately continuous reflections. The upper contact tends to have a toplap or erosional boundary whereas the lower surface tends to have a downlapping and commonly erosional signature. This facies is not present at the surface but was observed locally in the shallow subsurface with dips of inclined surfaces approximately parallel to the coast. Radar facies 2 is $\sim 2 \mathrm{~m}$ thick.

Radar facies 3 (Fig. 4d, e) has sinuous, horizontal to dipping, parallel reflections that are moderately continuous. The upper boundaries are concordant whereas the lower boundaries exhibit erosion. Inclined surfaces dip approximately toward the offshore. This facies is $\sim 4 \mathrm{~m}$ thick.

Radar facies 4 (Fig. 4c), a minor component, has low-amplitude, discontinuous reflections that are locally associated with radar facies 3 . Where present, this facies is less than $2 \mathrm{~m}$ thick.

Figure 5 shows radargram core intersections for five cores. Core 3 intersected the center "U" of radar facies 2 at a depth of $\sim 5 \mathrm{~m}$ (Fig. 5a). Cores 5 and 9, adjacent to the Eel River marsh, intersect horizontally stratified layers of radar facies 1 (Fig. 5b, c). Cores 10 and 11 in an area of beach ridges near Fox Point intersect dipping strata of radar facies 3, representing beach ridge cross sections (Fig. 5d, e).

At all four seismic locations (Fig. 2a), the top sediment was a thin $(0.5-1.5 \mathrm{~m})$ layer of dry sand and soil, as inferred from hand drilling at shotgun source locations and slow Pwave velocities. Unconsolidated sediment below was wet sand based on drilling and its higher acoustic velocity (Table 2). The depth to basement (interpreted as top of 

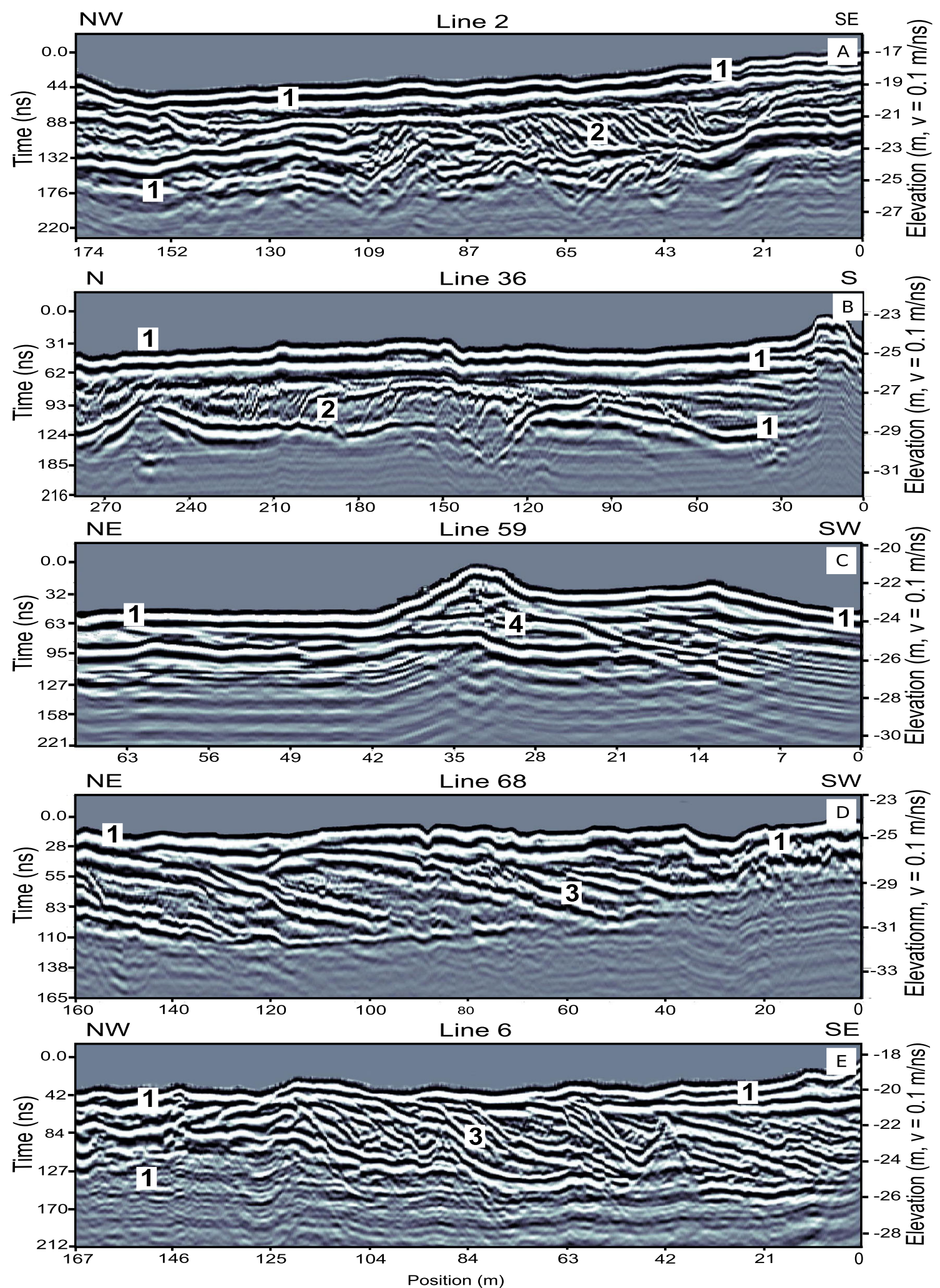

Fig. 4 Examples of Conrads Beach radargrams acquired using a $100 \mathrm{MHz}$ antenna (see text for interpretation and Fig. 2a for locations). Also shown are interpreted radar facies

Ordovician strata) was $\sim 20 \mathrm{~m}$ for all locations except West Beach where it was $\sim 10 \mathrm{~m}$ (Table 2). These results indicate that the GPR profiles imaged most of the sediment package at West Beach (Fig. 2b, seismic location 3) and the upper one third of the unlithified sedimentary package elsewhere. 

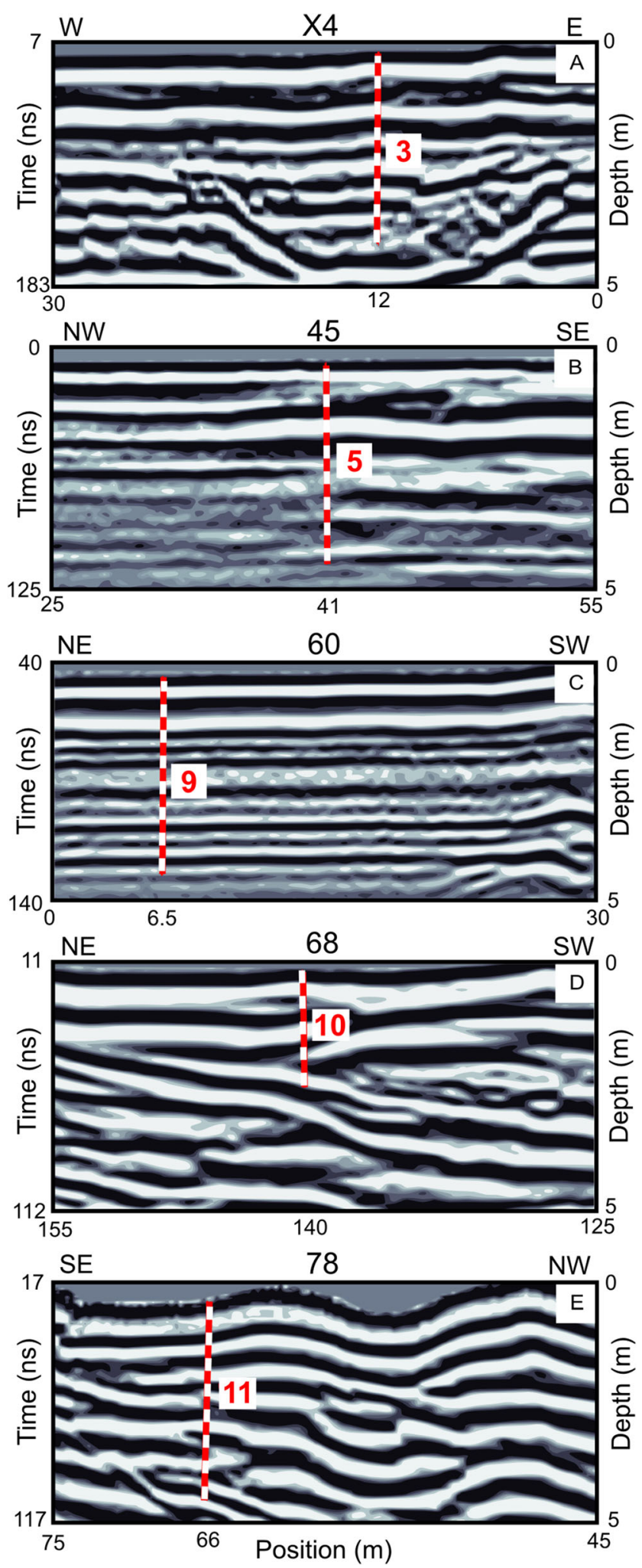

Fig. 5 Radargrams ( $30 \mathrm{~m}$ wide by $5 \mathrm{~m}$ deep) showing detailed structure associated with cores for which radiocarbon ages were obtained. The GPR traverses were acquired using a $100 \mathrm{MHz}$ antenna. Depths in each part of the figure (a-e) are given with respect to an arbitrary datum located near the maximum ground elevation within the individual panel. The nearest vibracore locations are indicated with dashed lines and the core lengths are shown to scale (see Fig. $2 \mathrm{~b}$ for core sites)
Table 2 Refraction seismic results

\begin{tabular}{lccc}
\hline Location & Layer & Thickness (m) & Velocity (m/s) \\
\hline 1) 2007 Boardwalk & 1 & 0.5 & 300 \\
& 2 & 18.5 & 1800 \\
& 3 & & 4300 \\
2) 2007 Center Beach & 1 & 1.0 & 300 \\
& 2 & 21.5 & 1500 \\
3) 2011 West Beach & 3 & & 3300 \\
& 1 & 1.0 & 300 \\
& 2 & 9.5 & 1500 \\
4) 2012 Fox Point & 3 & & 4700 \\
& 1 & 1.5 & 300 \\
& 2 & 22.0 & 1500 \\
\hline
\end{tabular}

\section{Core Results}

\section{Lithofacies}

Eight lithofacies were identified based on sediment size and texture, color, and the presence or absence of shell fragments and organic material (Table 3). Figure 6 shows the core sections and facies positioned with respect to their elevations relative to mean sea level. We devised the confidence indicator to indicate the lowest depth in each radargram with reliable GPR returns. For the majority of the cores, the confidence indicator from the nearest radargram is at or near the bottom of the core (Fig. 6), suggesting the radargrams and vibracores are providing information about the same subsurface interval. In the case of core 7, the confidence indicator is about halfway down the core (Fig. 6), so the core is providing significantly more subsurface information than the nearest radargram.

Facies 1-3 form sheets up to $1.2 \mathrm{~m}$ thick of relatively coarse material that constitutes $\sim 13 \%$ of the cores, mainly in the western part of the study area (Fig. 6). Based on the geomorphic settings of the cores and correlation with GPR profiles, these facies represent tidal channel, beach, and washover deposits. Facies 1 comprises cobbles and pebbles to coarse sand with numerous shell fragments and fine roots near the tops of some cores. Gravel is a component at depth in tidal channel deposits in cores 2 and 3 and at a low level in core 4, drilled through dunes. Coarse-grained sand is present at depth in cores 1-4 and at the top of cores 5 and 8 on the marsh fringe. There it is interpreted as coarse washover deposits. Coarse-grained sand near the bottom of core 11, drilled through beach ridges, may represent an underlying foreshore. Gravel at the base of core 6 is also interpreted as a coarse washover deposit.

Facies 2 comprises coarse to medium sand, and facies 3 comprises slightly finer sand on average. These facies are prominent in tidal channel deposits, within dune deposits, and in the 


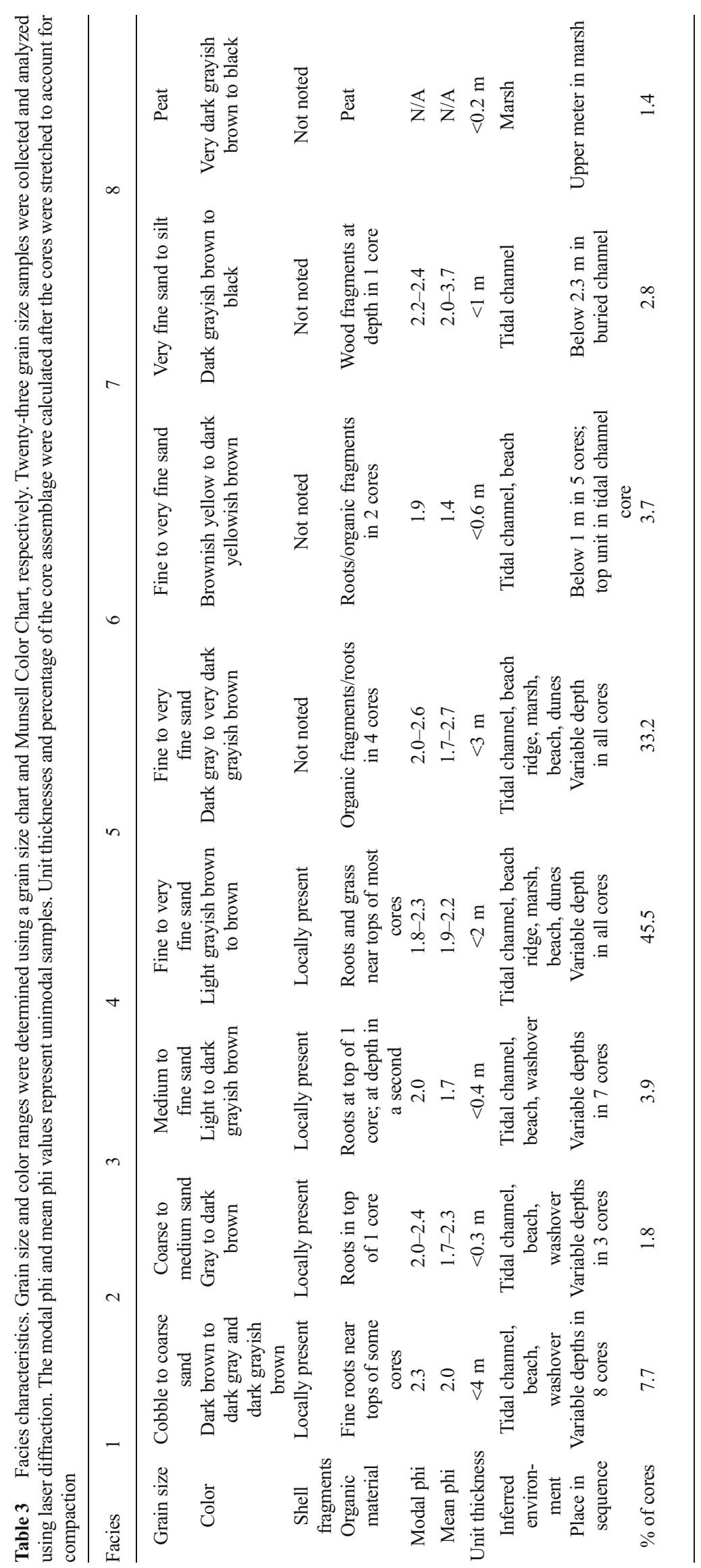


Fig. 6 Lithofacies distribution and sediment types for Conrads Beach vibracores (see Table 3 and text for facies descriptions). Inset shows the core locations

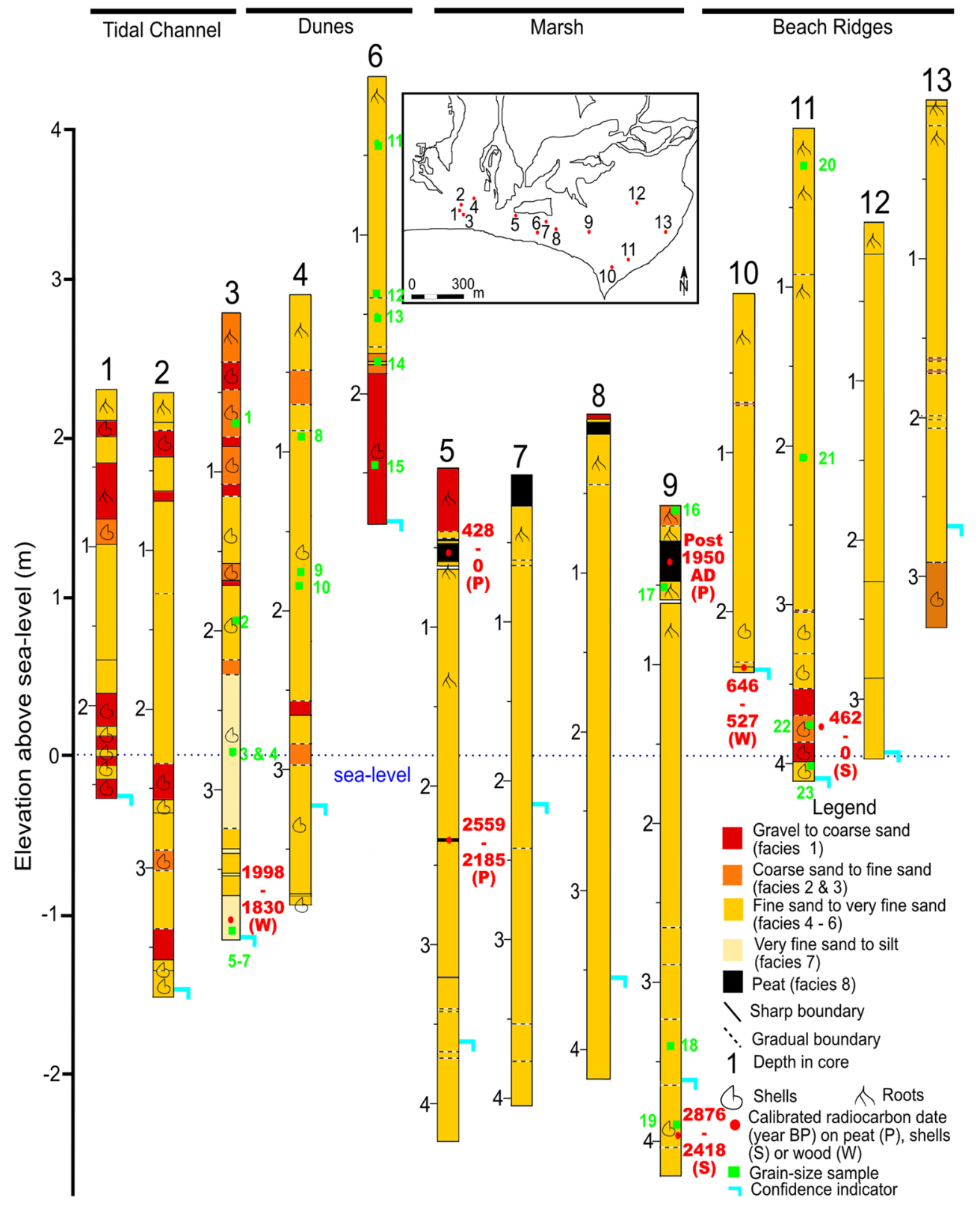

topmost parts of marsh deposits. In the latter two settings, they probably represent washover layers.

Facies 4-7 (fine to very fine sand with some silt) constitute the bulk of sediment in all cores ( $~ 85 \%)$ in units up to $3 \mathrm{~m}$ thick, especially through the beach ridges, dunes, and bordering the marsh. Roots and grass are common in facies 4 in near-surface sites, and these facies also contain a few shell fragments, which were not noted in other facies. The finer facies 7 is present only in the lower part of the tidal channel fill in core 3.

Facies 8 is peat and constitutes less than $2 \%$ of the cores. Peat occurs in layers less than $0.2 \mathrm{~m}$ thick just below the surface in four cores $(5,7,8,9)$ drilled through the marsh.

Figure 7 compares the dated vibracores with $3 \mathrm{~m}$ slices of their associated radargrams at the same vertical scale (see Fig. 5 for larger radargrams). Correlation between the radargram slices and the vibracore lithofacies is subtle. Some core lithofacies are not clearly identifiable in the GPR, and some GPR interfaces do not correspond to textural changes in the cores. Several factors may affect the correlation. Compaction during coring was likely non-linear and the stretching factor may have positioned the core lithofacies incorrectly. The constant velocity used for depth conversion is only an approximation and may have contributed to inaccuracies in the depth positioning of reflection events on radargrams. The GPR may have detected variations in sediment attributes that are not reflected in the core logs. Some core lithofacies may have been too thin for GPR detection. Plotting all lithofacies separately and using a higher GPR antenna frequency might have improved the correlation. Fine to very fine sand of facies 4 (46\% of the core sediments) and facies 5 (33\%) proved 
Fig. 7 Dated cores and associated radargrams. Five cores contained material suitable for radiocarbon dating.

Corresponding sections of GPR traverses $3 \mathrm{~m}$ long, centered at cores 3,9 , and 11 , and closest to cores 5 and 10 are shown to vertical scale, with the vibracore locations shown in the inset. See Fig. 4 for extended GPR images

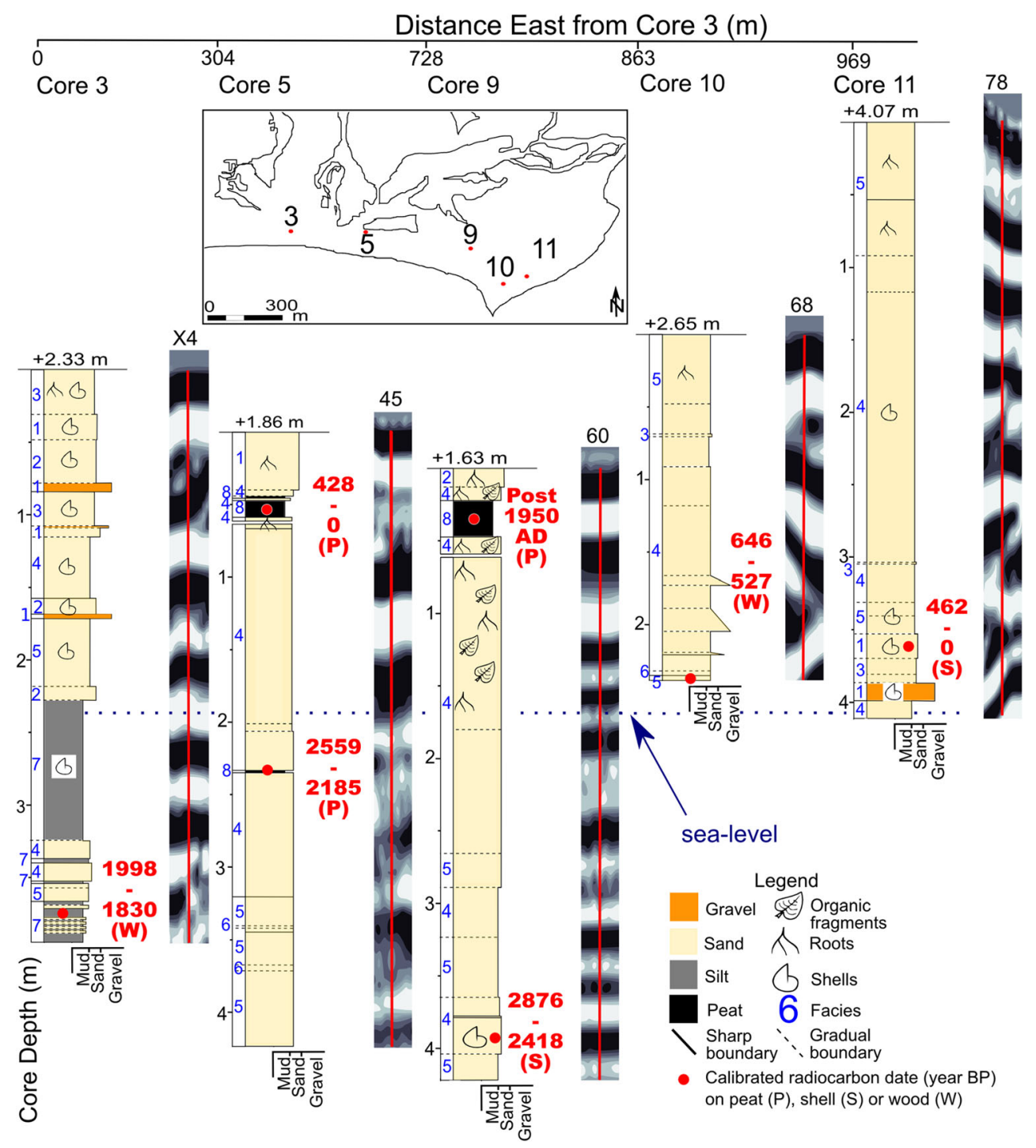

difficult to distinguish, and a higher antenna frequency would have decreased the penetration depth (Neal 2004). Lastly and perhaps most significantly, the textural uniformity of the sand precluded strong GPR reflections. Overall, the GPR radargrams provide larger scale structural information while the cores provide finer scale data regarding texture and composition.

\section{Grain Size}

In view of the predominance of facies 4-7 in all cores, grain size analysis was conducted to provide additional insight regarding the depositional environment based on plots of grain size parameters (Folk and Ward 1957; Friedman 1961; Blott and Pye 2001). Sample positions are shown in Fig. 6 (small squares). Samples 3, 4,12 , and 13 have bimodal distributions and sample 23 has a polymodal distribution. All other samples are unimodal.

Figure 8 shows grain size parameters for Conrads Beach samples classified by their inferred depositional setting (based on geomorphic setting and correlation with GPR profiles), in relation to Friedman's (1961) divisions. For Fig. 8a, Friedman's (1961) data indicate that beach sand generally has negative skewness and dune sand has positive skewness. The core samples are broadly distributed across Friedman's beach and dune fields, with most inferred beach ridge samples plotting in the beach field but with greater scatter in inferred dune samples. For Fig. 8b, Friedman's (1961) data indicate that dune sands are better sorted than river sands but with a large region of overlap and poor discrimination. The core samples are poorly discriminated, but tidal channel deposits show moderate to poor sorting and mainly plot in the river field.

In summary, grain size parameters provide some confirmation that the core samples have been correctly attributed to depositional settings, although the level of discrimination is modest. With such a short sand transport distance from nearby till sources to the beach and from the foreshore to bordering dunes and beach ridges, textural changes may have been slight, 


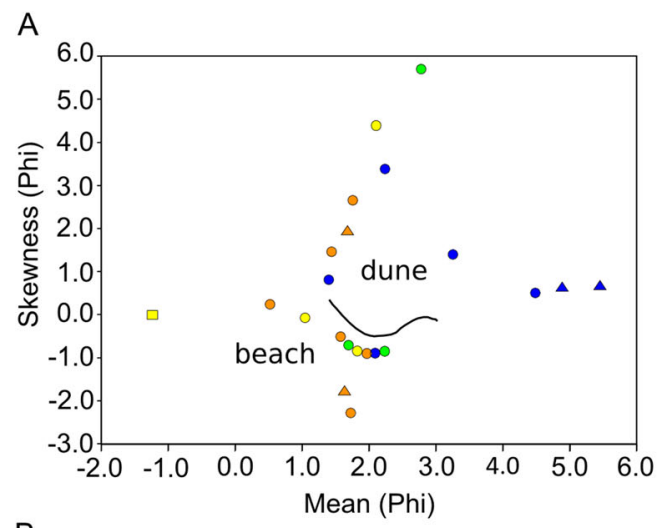

B

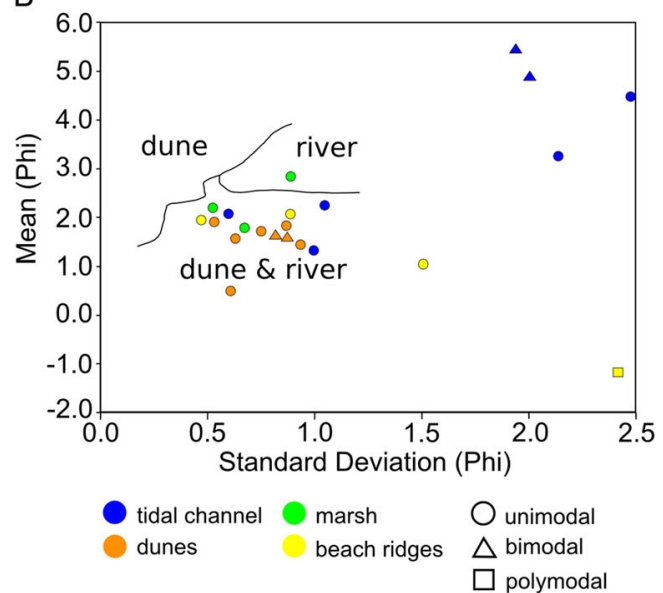

Fig. 8 Comparison of grain size data using $\phi$ (phi) [negative $\log _{2}$ ] scale to Friedman (1961) divisions

mitigating against the use of these parameters for discrimination. However, some similarity of river and tidal channel processes might be expected, and this appears to be the case.

\section{Radiocarbon Dating Results}

The dated samples in five vibracores (Table 4) were from four depositional environments: tidal channel, marsh, beach ridge, and dunes (Fig. 2a). Samples are reliably attributed to environments based on correlation with GPR profiles. The only exception was the lowermost sample in core 9, which lies below the confidence indicator (Fig. 6) in the associated radargram. The measured radiocarbon age (Table 4 ) is the measured age in radiocarbon years before present (AD 1950), whereas the conventional age is the measured radiocarbon age corrected for isotopic fractionation using $\delta^{13} \mathrm{C}$. The calibrated (calendar year) age is the conventional age calibrated using Calib7.0, and these ages are discussed here.

Samples 56 and 57 were collected low in beach ridge cores 10 and 11, $106 \mathrm{~m}$ apart (Fig. 7, Table 4), and returned calibrated ages of less than 650 years BP. Given their similar elevations,

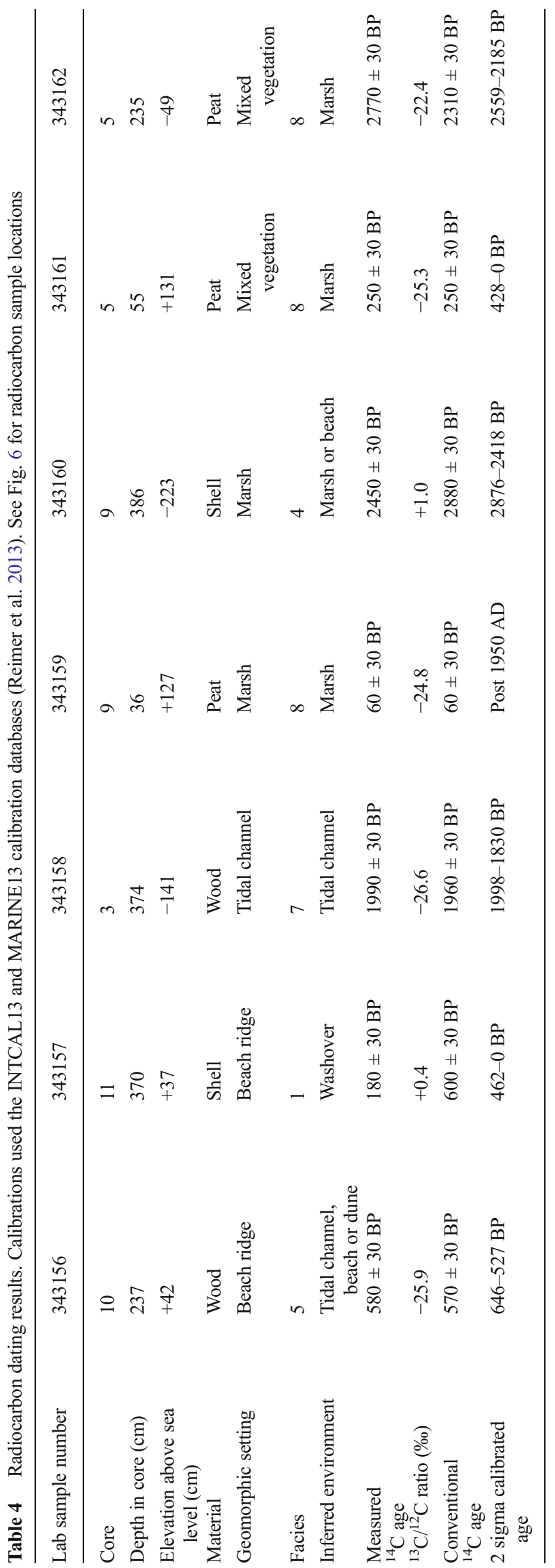


close proximity, and geomorphic setting, it is reasonable to expect these sample ages to be the same within error.

Samples 59 and 61 were from peat in the tops of cores 5 and 9, bordering the marsh and $424 \mathrm{~m}$ apart. They have similar elevations (Fig. 6, Table 4) and returned calibrated dates of less than 428 years BP and post $1950 \mathrm{AD}$, respectively. While the depositional environments and depths in core are similar, the difference in dates may reflect their distance apart $(450 \mathrm{~m})$ and local washovers that may have laid down sufficient coarse sediment to halt peat production at the site of core 5. Gravel or coarse sand is present in the top of that core.

Samples 58, 60, and 62 are below sea level (Figs. 6 and 7, Table 4) and were taken from cores 5 and 9 bordering the modern marsh and from the basal sediments of the tidal channel in core 3. They show a range of calibrated ages from 2876 to 1830 years BP. The deepest sample (60) at $\sim 2 \mathrm{~m}$ below sea level in core 9 is the oldest, and the tidal channel sample (58) at a mid-elevation is younger than sample 62 above. This apparent stratigraphic reversal may reflect preservation of tidal channel sediments cut into older sediments or the reworking of sample 58. As discussed below, the tidal channel deposits may be composite because a relatively old radiocarbon date was obtained for the lower part whereas the upper part is known from historical records to have been abandoned recently.

\section{Historical Evidence for Geomorphological Change}

Both natural and anthropogenic events (Table 5) may have contributed to changes at Conrads Beach. Agriculture was a prominent activity that transformed the landscape when Europeans first settled the area. In order to increase the amount of agriculturally viable land, Acadian settlers constructed a bridge and dike at the entrance to Eel River (Degen 1979), and marsh hay was being farmed as early as the mid-1700s (Taylor et al. 1996). More recently and persisting until $\sim 30$ years ago, there was also active extraction of sand and gravel.

Table 5 Natural and anthropogenic events affecting Conrads Beach

\begin{tabular}{|c|c|}
\hline Date & Event \\
\hline Just prior to 1752 & $\begin{array}{l}\text { The Acadians, the first European settlers, may have built } \\
\text { an aboiteau (dike with bridge) at the entrance to West Marsh (Degen 1979). }\end{array}$ \\
\hline 1754 & British settled at Lawrencetown, close to West Marsh (Degen 1979). \\
\hline $1798-1857$ & Seven major storms known to have damaged the Halifax area (Degen 1979; Delure 1983). \\
\hline 1881 & $\begin{array}{l}521 \text { residents of Lawrencetown practice farming, fishing, and trades with } 412 \\
\text { acres of cultivated land and } 375 \text { acres of reclaimed marsh (Degen 1979). }\end{array}$ \\
\hline Early 1900 s & A heavy storm subdivides Egg Island (subsequently all soil washed away) (Degen 1979). \\
\hline September 11, 1954 & Hurricane Edna impacts the Halifax area (DeIure 1983). \\
\hline December 30, 1956 & $\begin{array}{l}\text { Severe wind storm knocks down } 1000 \text { trees in Point Pleasant Park and tosses barges on } \\
\text { shore in Dartmouth (DeIure 1983). }\end{array}$ \\
\hline 1962 & Opening of a tidal channel along the western shore of Conrads Beach (Taylor et al. 1985). \\
\hline August 16, 1971 & Hurricane Beth causes record rainfall and flooding in Halifax (DeIure 1983). \\
\hline September 15-16, 1996 & $\begin{array}{l}\text { Hurricane Hortense's significant wave heights of } 8.7 \mathrm{~m} \text { result in flooding in Lawrencetown } \\
\text { (Taylor et al. 1997). }\end{array}$ \\
\hline September 29, 2003 & $\begin{array}{l}\text { Hurricane Juan damages Lawrencetown Beach, destroying boardwalks, cutting back } \\
\text { dunes by } 5.5 \text { m, and scouring upper beach, resulting in loss of the cobbles that had } \\
\text { accumulated since February } 1998 \text { (NRCan 2011). }\end{array}$ \\
\hline November 3-4, 2007 & $\begin{array}{l}\text { Post-tropical Storm Noel damages Conrads Beach by flooding and scouring the boardwalk } \\
\text { and eroding and lowering the upper beach (Taylor et al. 2008). }\end{array}$ \\
\hline August 22-23, 2009 & Hurricane Bill causes flooding at Conrads Beach (NRCan 2011). \\
\hline September 4, 2010 & $\begin{array}{l}\text { Hurricane Earl (NRCan 2011). Halifax Harbour had a storm surge of } 1.15 \mathrm{~m} \text { that coincided } \\
\text { with low tide. The maximum total water level was } 1.83 \mathrm{~m} \text {. Wave heights of } 10.1 \mathrm{~m} \text { with } \\
\text { a peak of } 25.1 \mathrm{~m} \text {. Upper beach and dunes along the south-facing beach at Conrads Beach } \\
\text { were trimmed, exposing the cobble substrate. East of Fox Point, the dunes were severely } \\
\text { cut. Small landward extent of overwash. "Smearing" of a sand ridge and transfer of large } \\
\text { sediment volume to sea at Lawrencetown Beach. }\end{array}$ \\
\hline December 2010 & $\begin{array}{l}\text { Four storms damaged Conrads Beach (Taylor et al. 2013). The pedestrian bridge and backshore } \\
\text { were flooded. On the western beach, furrows were etched into the embryo dunes and the } \\
\text { beach was lowered to expose the pebble-cobble dune base. Waves from the December } 27 \\
\text { storm washed } 53 \mathrm{~m} \text { inland at the buried channel. On the central beach, the beach was lowered } \\
\text { and the dunes cut back by } 5 \mathrm{~m} \text {. Along the eastern beach, total dune retreat was } 9.1 \mathrm{~m} \text {. }\end{array}$ \\
\hline
\end{tabular}


The earliest map (1779) with a sufficiently large scale to show Conrads Beach (Fig. 9a) shows that the southernmost tip of the beach was a peninsula $\sim 500 \mathrm{~m}$ long (Taylor et al. 1985). The western shore was oriented northwest-southeast, the eastern shore was oriented approximately north-south, and the channel between Conrads Beach and Lawrencetown Beach was $\sim 500 \mathrm{~m}$ wide. By 1865 (Fig. 9b) (Church 1865), Egg Island and Eel River had been named, Fox Point appears shorter and wider, and Eel River cuts southwest. Although not shown in the 1865 map, settlers began constructing a dike across the mouth of Eel River in 1830 (Degen 1979) and this feature is visible on the geological map by Faribault (1906). Prior to the early 1900s, Egg Island was a forested island $\sim 800 \mathrm{~m}$ south of Fox Point (Degen 1979). Lawrencetown Dike (across Eel River) was deliberately destroyed in 1917, and a wharf was constructed on Fox Island in 1920 (Degen 1979).

By 1954 (Fig. 9c), Conrads Beach had attained its modern shape. Notable features include increased deposition east of Fox Point, shoreline retreat at Fox Point and Fox Island, increased marsh west of Fox Point, and decreased beach width adjacent to West Marsh. A system of trails east of the boardwalk and two bare areas (east and west of GSC-001) suggest continued anthropogenic change. In 1962, a tidal channel opened $\sim 270 \mathrm{~m}$ west of the boardwalk (Taylor et al. 1985).

By 1973, Egg Island was completely submerged (Fig. 9d). The 1973 and 1992 photographs (Fig. 9d, e) show an open tidal channel in the western part of the study area and closure and burial of the tidal channel by 1989 (Taylor et al. 1996). The 1992 photo (Fig. 9e) shows a sandy zone $\sim 200 \mathrm{~m}$ wide covering the former position of the tidal channel and an increased beach width to the west. West Marsh is considerably smaller than in earlier photos and some former marsh areas appear vegetated with non-marsh species. Areas east of Fox Point, Conrads Beach, and Eel River also show evidence of increased sand deposition. The 1992 aerial video (Taylor and Frobel 2001) shows a large gravel shoal south of Fox Island, the lag shoal remnant platform of the planed-off drumlin (Taylor et al. 1996; Forbes 2005, 2011).

The most recent image in the sequence is from 2013 (Fig. 9f). After several major events over the previous decade (Table 5), Fox Island is almost entirely submerged, and vegetation in the area of the buried tidal channel and reclaimed marsh is sufficiently dense to obscure surface traces of these features. At low tide, remnants of the Fox Island wharf are visible. Fox Island has continued to decrease in size, and Eel River has continued to narrow, with vegetation well established on the sand bars fringing the tidal inlet.

Vegetation lines digitized from the georeferenced maps and photographs (Fig. 10) show changes in the extent of vegetation due to the opening and closing of the tidal channel. In 2003 Hurricane Juan resulted in a considerable reduction of vegetation by dune erosion and washover deposition on the western side of Conrads Beach (Fig. 10). West of Fox Point, the long-term trend is a landward retreat of the outer limit of vegetation (Fig. 10), amounting to $\sim 150 \mathrm{~m}$ between 1865 and 1945. West of the tidal channel, the vegetation line retreated steadily until the channel opened in 1962. After the channel closed in 1989, the vegetation line was re-established just north of the 1972 position, since when it has continued a slow landward movement. Between the tidal channel and Fox Point, the vegetation line has remained stable despite short periods of landward retreat and seaward advance associated with seasonal or longer term adjustments in the upper beach and dunes.

East of Fox Point, retreat of the vegetation line was interrupted by periods of progradation (Fig. 10). There was significant deposition between 1865 and 1945, but the 1954 and 1960 vegetation lines overlap the 1945 line along the southeast-facing portion of the beach, suggesting approximate stasis. The east-facing part of the beach to the north experienced landward recession (or tidal channel migration) during this period. By 1974, the entire eastern beach was experiencing erosion. The period from 1974 to 1992 was one of progradation for the southeast-facing beach, while the eastfacing beach retreated a maximum of $17 \mathrm{~m}$. Considerable recession of $\sim 30 \mathrm{~m}$ occurred between 1997 and 2002, and the entire eastern beach has experienced erosion since then. At Fox Island, continued erosion since 1865 has resulted in the drowning of a boulder lag shoal.

\section{Discussion}

In trenches at Conrads Beach and elsewhere along the Nova Scotia coast, the modern foreshore shows well-stratified sand and gravel and the modern lagoonal fringe shows interbedded planar units of organic-rich mud and sand-gravel, the latter interpreted as washover deposits associated with storms (Carter et al. 1990; Nichol and Boyd 1993). These structures are the likely source of the observed reflections associated with radar facies 1 (Fig. 4). Radar facies 2 (Fig. 4a, b) represents a tidal channel that migrated $\sim 60 \mathrm{~m}$ to the southeast before it was filled and buried. The dipping reflectors represent the progressively advancing accretionary bank of the channel. Their sigmoidal form indicates near-complete preservation of the bank sediments, yielding a vertical extent of about $2 \mathrm{~m}$ that approximates the original channel depth. Below and southeast of the channel body are closely spaced subparallel reflectors, possibly beach sediment associated with the tidal channel. This channel originally connected the lagoons of West Marsh and Eel River to the ocean. Radar facies 3 (Fig. 4d, e) is best developed below the beach ridges, with local scours at depth. In some areas, radar facies 3 is located below present-day dunes and is interpreted as dune flank deposits. Radar facies 4 (Fig. 4c) is interpreted as poorly 
Fig. 9 Topographic changes at Conrads Beach since 1779. Key events include the erosion of Egg Island (b) and Fox Island (c), the creation (d) and filling (e) of a tidal channel, and increased sedimentation in Eel River and West Marsh (e, f). The 1779 map (a) is taken from Taylor et al. (1985), and the 1865 map (b) is simplified from Church (1865). The 1954 aerial photograph (c) is from the National Air Photo Library; 1973 (d) and 1992 (e) from Nova Scotia Natural Resources; and 2013 (f) from Google Maps 2013 (CNES/SPOT Image, Digital Globe). The 1865 to 2013 maps and photos were georectified in ArcGIS and referenced to the GSC-001 (Geological Survey of Canada) benchmark (triangle)
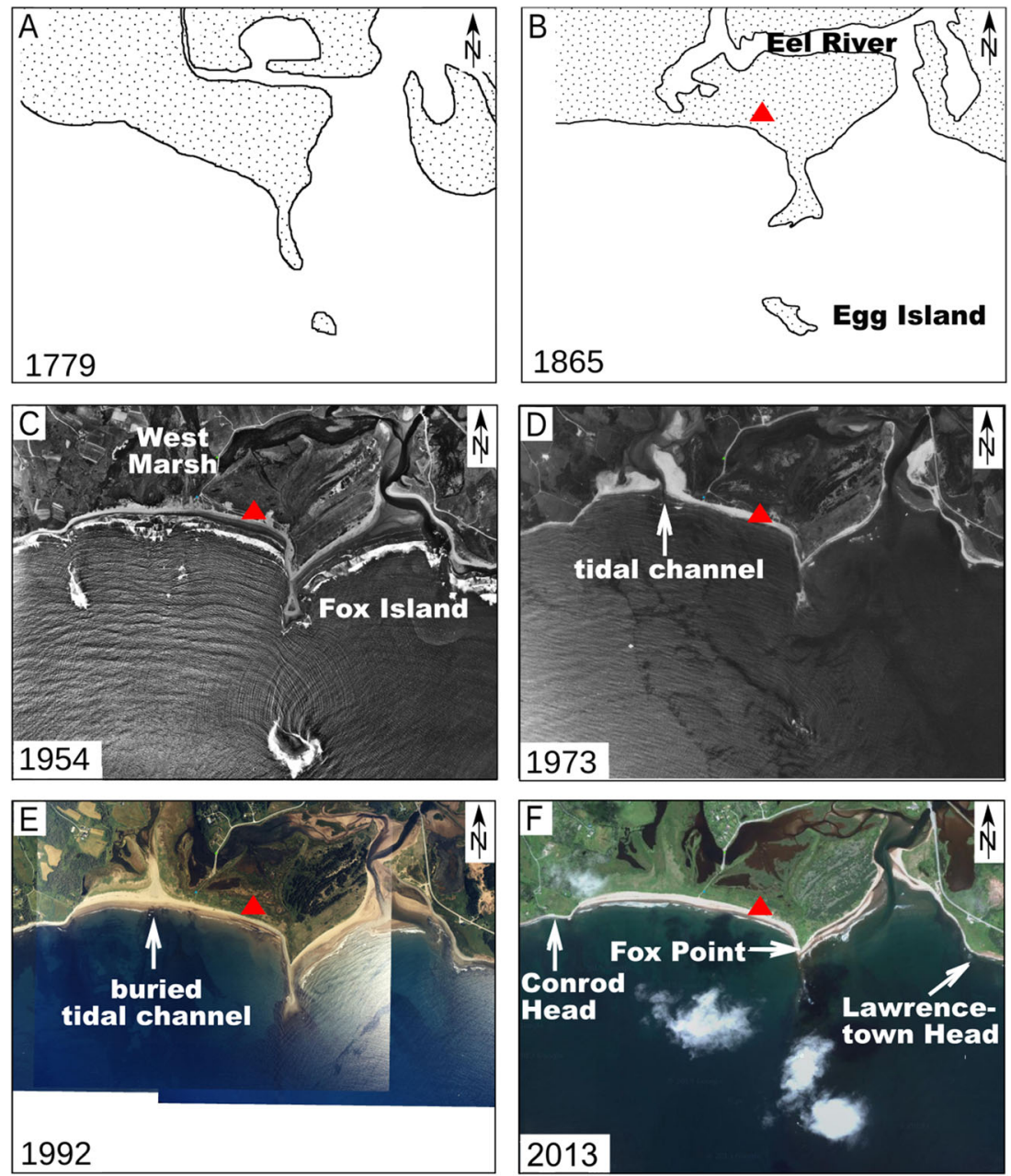

GSC-001 benchmark

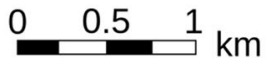

Fig. 10 Conrads Beach seaward limit of vegetation over time. This shows long-term (centennial) changes in the vegetated area from 1865 to 2013.

Anthropogenic changes in 1960 (dotted line) and the effects of Hurricane Juan in 2003 (dashed line) are also shown. The 1865 vegetation line was determined by first assuming that the map shows the location of the shoreline and then by removing the average distance from the shore to the vegetation line observed in the succeeding years

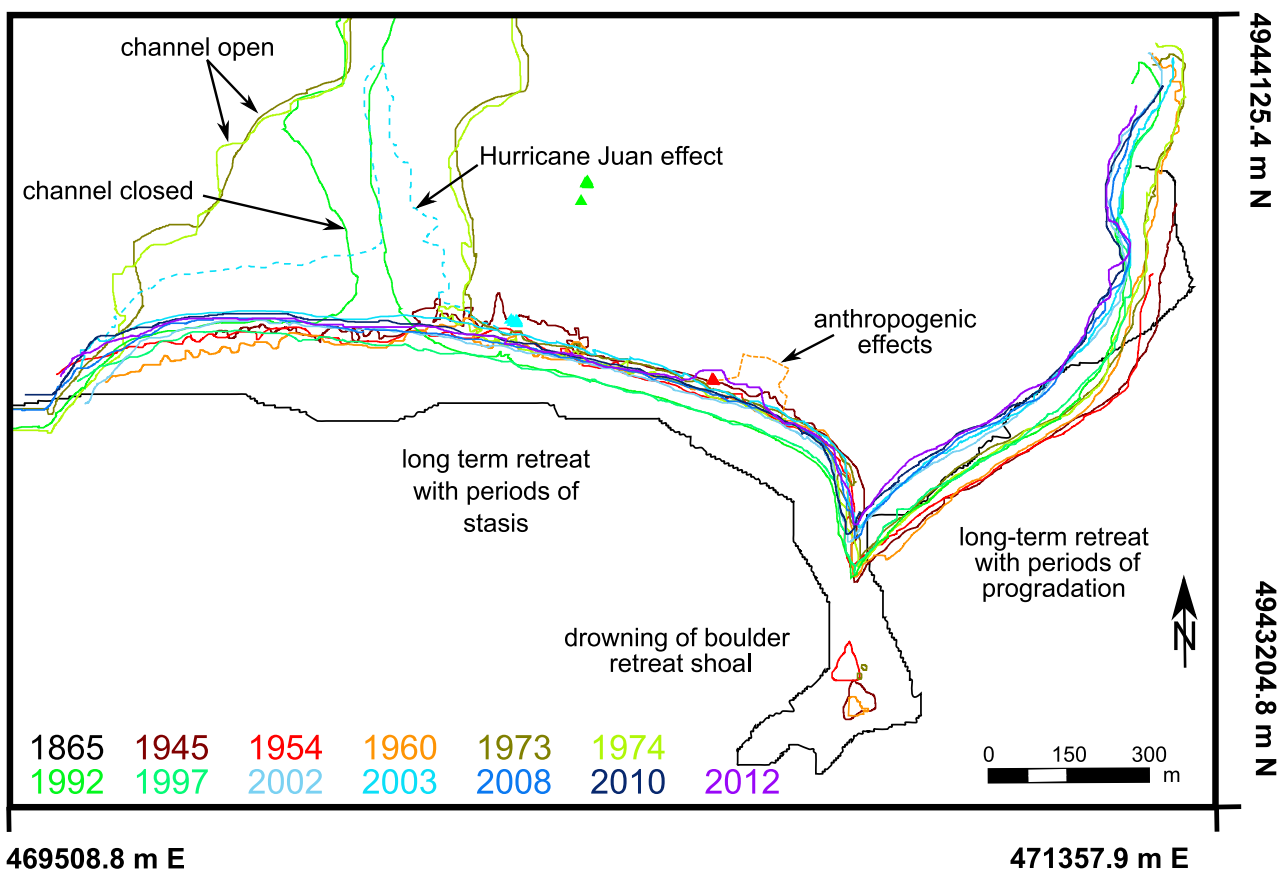


stratified material within extensive dunes and smaller dune areas associated with beach ridges.

The oldest dated sample, on shell fragments in sand, near the base of core 9 (at $\sim 2 \mathrm{~m}$ below present sea level), yielded a date of 2876-2418 years BP (Figs. 6 and 7, Table 4). Although the sample was located slightly below the confidence indicator (Fig. 6), strata throughout the profile appear flat lying and are attributed to radar facies 1 , in accord with a beach or marsh setting (Fig. 5c). A beach setting is supported by the presence of shells, although the grain size data for sample 19 plot in the dune field (Fig. 8a). Three other cores $(5,7$, and 8$)$ are close to core 9 and extend to similar depths, but none yielded shell fragments in their lower parts (Fig. 6). We provisionally suggest that the core site lay close to or below sea level at this time, perhaps in the littoral zone of an estuary behind the Egg Island drumlin. An open estuary may have covered the low-lying West Marsh-Eel River area and, perhaps, much of the Conrads Beach area at that time.

The next oldest date (2559-2185 BP) was obtained from core 5 at $\sim 0.5 \mathrm{~m}$ below modern sea level (Fig. 6). The sample was collected from a thin organic layer, but the lack of roots below it suggests that the material was reworked, rather than being an in situ peat. No shell fragments were noted, but the GPR profile shows good layering of radar facies 1 . As inferred from core 9, the area may have been very shallow or littoral at this time.

Cores 10 and 11 produced dates of 646-527 BP and 462-0 BP, respectively (Figs. 6 and 7, Table 4). In both cases, dated materials were near the bottom of the core and less than $50 \mathrm{~cm}$ above present sea level. The two cores were drilled near the fringe of the beach ridge area and $\sim 50 \mathrm{~m}$ from the eastern shore (Figs. 2, 6 and 7). For core 11, the date was from shell material in relatively coarse sediment with inclined reflections attributed to radar facies 3 , and represents the lower strata of the beach ridge system. Sample 22 from this level yielded equivocal grain size results. For core 10, the dated sample was a wood fragment in finer sediment of radar facies 3 with shell fragments above. Cores 12 and 13 were also drilled in the beach ridge area but neither yielded material suitable for dating. The dates from cores 10 and 11 suggest that beach ridge initiation took place $>600$ years ago, and age/depth relations for the cores suggest rapid sediment buildup thereafter. Eroding drumlins at Fox Island and nearby Egg Island probably supplied most of the sediment for the beach ridges, while also providing shelter for accumulation of beach sand (Boyd et al. 1987; Taylor et al. 1996). Lag shoals seaward of the western beach mark the location of one or more other drumlins that would have provided sediment to a precursor of Conrads Beach and additional shelter to an estuary behind it in the West Marsh-Eel River basin (Taylor et al. 1985, 1996). Over time, the landward progression of an erosional front (Carter et al. 1989) has consumed these earlier headlands, increasing exposure of the beach ridge complex to highenergy waves.
Peat samples from the topmost levels in cores 5 and 9 near the Eel River marsh fringe yielded dates of 428-0 BP and post 1950 AD, respectively (Table 4). Along with shallow peats in two undated cores (7 and 8), these dates suggest extensive peat formation in this area within the past 400 years. Rooted zones at greater depth in all four cores suggest an earlier vegetation cover. These results suggest that Eel River has been a lagoon for a prolonged period, owing its isolation in part to the nearby beach ridges, over at least the past 600 years.

Core 3 was drilled through the buried tidal channel behind the western beach (Fig. 2, Table 4), and a wood sample at $374 \mathrm{~cm}$ depth ( $\sim 1 \mathrm{~m}$ below sea level) was extracted from it. The tidal channel is known to have been active between 1962 and 1989 (Taylor et al. 1996), but the date of 1998-1830 BP is considerably older than expected. The GPR profile (Fig. 4a) shows a well-marked erosional cut below the base of the core. These attributes may be consistent with a channel-margin depositional setting. Three other cores $(1,2$, and 4$)$ were drilled through the channel fill, as confirmed from GPR lines (Fig. 2a), and all four cores contain relatively coarse, pebbly sediment and shell fragments. These observations collectively suggest that the core has been correctly classified as tidal channel sediments. Although the dated wood may lie within the fill of an older tidal channel cut by the younger channel, erosional surfaces are not apparent within the lower part of the cores and associated radargrams (Figs. 5 and 7). We conclude that the dated wood was reworked from older deposits, as suggested for material at depth in core 5.

Using aerial photography, satellite imagery, and map analysis, we have documented the past 235-year history of Conrads Beach, linking long-term shore development interpreted from subsurface data with recent coastal dynamics. A map from 1779 (Fig. 9a) shows little land east of Fox Point whereas the 1865 map (Fig. 9b) shows a considerable extension of the beach ridge area, which may have prograded until relatively recent times. Rates of erosion and deposition are non-uniform, but average rates can be calculated by comparing the vegetation lines (Fig. 10). The overall change from 1865 to 2012 has been retreat. The average rate of retreat was about $1.1 \pm 0.1 \mathrm{~m} /$ year from 1865 to 2012 near the middle of the western beach (south of the buried channel) and about $1.6 \pm 0.1 \mathrm{~m} /$ year along the eastern beach $(150 \mathrm{~m}$ northeast of Fox Point). Periods of progradation, stasis, and recession indicate a complex pattern of temporal and spatial variability in coastal evolution.

Profile analysis provides additional insight into recent medium-term (decadal) change. Changes to the western beach (Fig. 3, lines a, b) have been consistent with the changes seen in Fig. 10. The eastern transect (Fig. 3, line c) shows $\sim 2.4 \mathrm{~m} /$ year $(50 \mathrm{~m}$ in 21 years) of beach ridge/dune retreat. At its widest, the distance from the shore to the lagoonward edge of the beach ridges on the eastern beach is $\sim 430 \mathrm{~m}$ (Fig. 2a). Applying the recent eastern transect retreat rate, it would take 
$\sim 181$ years for the beach ridges to be eroded. On the western beach, $\sim 160 \mathrm{~m}$ of mixed vegetation, dunes, and beach lies between the shore and the marsh (Fig. 2a). If erosion here continued at a rate of $1.1 \pm 0.2 \mathrm{~m} /$ year, the western beach would be eroded in $\sim 145$ years, although the coastal system may maintain its form as it retreats. Accelerated sea level rise will likely cause the water levels in Eel River and West Marsh to rise, potentially inundating the marshes depending on the rate of vertical accretion. Anticipated effects of sea level rise include more frequent washover of beaches and potential destabilization of coastal dunes (Shaw et al. 1998). There is a high probability that a new tidal channel may develop in the future along the west beach, further reducing its longevity.

Correlation of air photos and satellite images with known recent events suggests that local shorelines eroded rapidly during extreme events, with medium-term (decadal) changes on both sides of Fox Point as the barrier system adjusted to changing environmental and sediment input conditions. The western beach showed steady recession on a century scale and was narrowing prior to the development of the tidal channel between 1954 and 1962. This was undoubtedly assisted by large-scale removal of beach sediment (Taylor et al. 1996). The eastern beach has alternately retreated and prograded, and the scarped foredunes drop steeply to the beach as a result of recent erosive events. Similarly, retreat of drumlin-fed barriers at the mouth of Chezzetcook Inlet has varied in response to decadal-scale changes in storm impacts and sediment supply (Carter et al. 1990; Forbes et al. 1995b, 1997; Taylor et al. 1996, 2014).

Maps confirm that the marsh was already established in the 1800 s, and coring indicates that new sediments slowly accumulated over it with progressively rising sea level. Coarser sediments in the topmost parts of cores 5, 8 , and 9 in this area suggest increased washover deposition from the present beach in recent times, in accord with landward migration of the barrier. The Egg Island-Fox Island drumlin complex has been progressively eroded through this period, leaving boulder retreat shoals over the former drumlin footprint and trailing shoals in its lee (Boyd et al. 1987; Carter et al. 1987, 1990; Taylor et al. 1996).

On a longer time scale, the coastal system is transgressive, with an erosional front progressing landward (Carter et al. 1989; Forbes 2005, 2011). The landward retreat of the shoreline is punctuated by local progradation as drumlin sediment sources become available (Boyd et al. 1987; Forbes et al. 1995b; Forbes 2005, 2011). The Conrod Head drumlin currently anchors the western side of the beach, and Lawrencetown Head (a much smaller drumlin) anchors the eastern side. The oldest dated sediment in the cores yields evidence that the area was likely estuarine behind a former barrier or barriers attached to these two drumlins, another in front of the western beach, and the Fox Island-Egg Island drumlins some 2500 to 3000 years ago. Shallow seismic data from the inner shelf reveal the presence of estuarine facies comparable to those forming in Lawrencetown Lake today, supporting the interpretation of intermittent coastal retreat (e.g., Forbes et al. 1991b, 1995a) for several thousand years in a pattern similar to that reported here for the past few centuries and decades. After local southeastward progradation and beach ridge formation east of Fox Point over the past $>600$ years, barrier retreat was underway by the 1950s and possibly much earlier. Gradual retreat of Lawrencetown Head, the demise of the Egg Island headland, and removal of any earlier seaward barriers left the eastern beach progressively more exposed to the open ocean as sediment supply from Egg and Fox Islands was effectively switched off. While the Eel River outlet was probably active throughout the period of ridge formation, the breaching of Lawrencetown Inlet into Lawrencetown Lake occurred sometime between 800 and 200 years BP (Boyd and Honig 1992), after an inlet east of Lawrencetown Head was closed by littoral sediment transport from the east (Hoskin 1983). Once the present inlet was established, sand began to be carried through the inlet to form flood delta deposits in Lawrencetown Lake. This diverted and thereby further diminished the supply to the beach ridge complex.

Scott et al. (1995) showed that sea level was $\sim 21 \mathrm{~m}$ below present higher high water at large tide (HHWLT) at Chezzetcook Inlet 7000 years ago (Fig. 11). On the inner shelf, saltmarsh peat was accumulating in $34 \mathrm{~m}$ present water depth at 7500 years BP (Forbes et al. 1995a). Relative sea level (RSL) rise subsequently accelerated and then decelerated to approximately $1.6 \mathrm{~mm} /$ year from 4000 to about 150 years ago (Forbes et al. 1991a; Scott et al. 1995; Gehrels et al. 2004).

The depth vs. age positions of the beach ridge samples (56 and 57) and shallow peat samples (59 and 61) plot along the Scott et al. (1995) sea level curve (Fig. 11). The older samples

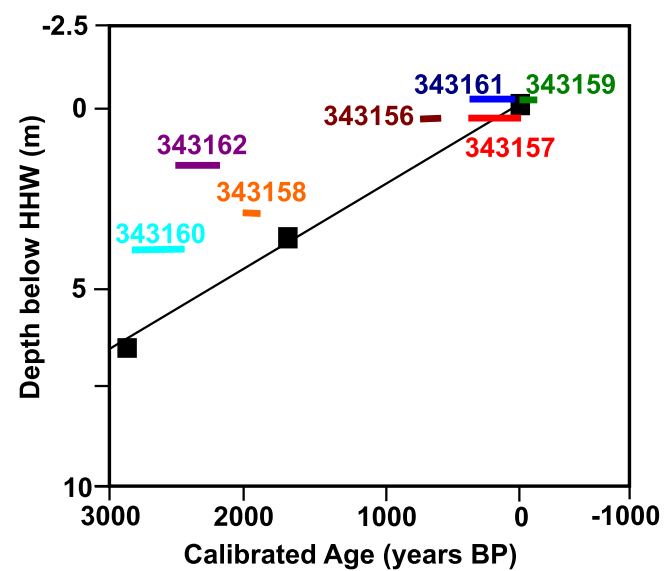

Fig. 11 Depth as a function of calibrated radiocarbon age for dated samples from Conrads Beach cores. Straight line and black squares are relative sea level data for Chezzetcook Inlet from Scott et al. (1995). See Table 4 for additional information regarding lab sample numbers 56-62 
that plot farthest from the RSL curve are 58 (tidal channel), 60 (deep shell), and 62 (deep peat). We suspect that sample 58 was reworked and not in situ. It is also possible that samples 60 and 62 are reworked.

Our results match well with those of Boyd and Honig (1992) and Nichol and Boyd (1993) who documented the history of Lawrencetown Lake, an estuary situated behind the barrier at Lawrencetown Head just east of our study area. Cores in the estuary terminated in brackish central basin muds that were dated at $3220 \pm 150$ years BP. An upward transition into coarser flood-tide delta sediments by $1990 \pm 130$ years BP represents sediment entering the lagoon through tidal inlets cut through the seaward barrier (Nichol and Boyd 1993). Erosion of the Half Island Point drumlin to the east (Fig. 1b) supplied this barrier through westward longshore sediment transport, eventually closing an earlier inlet to Lawrencetown Lake east of Lawrencetown Head through the development of spits and beach ridges. Our results are consistent with those of Hoskin (1983), who obtained an age of 700 years BP for beach ridge formation on eastern Lawrencetown Beach and $\sim 430$ years BP for closure of the inlet east of Lawrencetown Head (Boyd and Honig 1092).

As sea level continues to rise and the sediment supply diminishes, Conrads Beach will fail or be overtaken as another discrete package of glacial sediment is eventually used up (Boyd et al. 1987; Forbes 2011). The loss of the Egg Island drumlin has effectively shut off the sediment supply at the east end of the beach. Conrod Head is sufficiently large that it will continue to provide the western anchor for some time, but renewed breaching of the west beach is a distinct possibility as supply from the east is cut off. With further exposure of Fox Point, erosion in that area may ultimately begin to cannibalize the western end of the beach ridge complex, providing a shortterm renewed sediment supply at the eastern end of the west beach. As observed elsewhere along the Eastern Shore (Boyd et al. 1987; Taylor et al. 1996), the drumlin north of Conrads Beach may be tapped eventually as the erosional front moves landward (Forbes 2005, 2011), providing a new eastern anchor and sediment supply for a new barrier system in the inner West Marsh embayment.

The majority of the world's coastlines are transgressive (Boyd 2010), and more will become so with accelerated global sea level rise (Church et al. 2013; Woodroffe et al. 2014). The Conrads Beach case study presented here documents the history of barrier evolution on a transgressive, paraglacial coast where episodic sediment supply is highly sensitive to geomorphic change. The results show that barrier stability is closely related to short-term sediment supply, as well as exposure to storm wave events. Eroding headlands such as drumlins may temporarily delay coastal retreat or even cause progradation on time scales of a few centuries. This study has documented one such case in which there appears to have been a recent switch from progradation to erosion, highlighting the risks for coastal planning of assuming that recent rates of change are a guide to future rates. It demonstrates the potential complexity of coastal systems and the need for holistic analysis for projection of future coastal development in such settings. This case study of Conrads Beach may serve as a model for coastal morphosedimentary response to longterm transgression on other paraglacial or similarly complex coasts with limited sediment supply.

\section{Conclusions}

This study has provided a detailed description of the geomorphology and sedimentary architecture of a complex, paraglacial, barrier dune and inlet system on the Eastern Shore of Nova Scotia in Atlantic Canada. It has provided exceptional detail on the structure and morphosedimentary response of these coastal landforms to rising sea level and shifting exposure and sediment supply, consistent with the transgressive drumlin coast model previously developed in this region (Boyd et al. 1987; Nichol and Boyd 1993; Forbes 2011).

Our study has determined the time scale for the initiation and growth of a prograded beach ridge sequence in a backbarrier estuary or partially protected embayment, providing temporary sediment storage over several centuries before its eventual demise, as till headlands are cut back and exposure is increased.

This study has clarified the processes whereby barriers adjust to time- and source-varying sediment supply as an erosional front moves landward, progressively altering the coastal morphology and source-sink pathways for littoral sediment transport.

It is clear that coastal retreat in such a setting does not proceed in a linear fashion. Effective coastal management and hazard mitigation require a sophisticated understanding of the shifting patterns of sediment input and coastal response, which to some extent can be predicted with an understanding of the Eastern Shore model for a transgressive paraglacial coast.

Acknowledgments This research was funded by a Lew King Award to Forde and by Natural Sciences and Engineering Research Council (NSERC) Discovery Grants to Gibling and Nedimović. The authors thank D. O'Connor, P. Regan, T. Duffett, J. Thibodeau, A. Farkas, F. Walsh, B. Louis, K. Landry, H. Kuehn, and J. Evangelatos for assistance in the field. Dalhousie University Earth Sciences 2270 students from 2007 and 2010-2012 assisted with GPR acquisition and refraction seismic acquisition and data processing. O. Brown (Geological Survey of Canada) and P. MacAulay (Canadian Hydrographic Service) provided advice and assistance with grain size analyses and tidal datum issues, respectively. R.B. Taylor and D. Frobel (Geological Survey of Canada) provided aerial photographs of Conrads Beach and shared the results of many years of the beach surveys. We thank R.B. Taylor, Prof. D. van Proosdij (St. Mary's University), and Prof. R. Jamieson (Dalhousie 
University) for helpful discussion on aspects of this research. Special thanks to Mr. and Mrs. Welch and Mr. Hood, nearby landowners, for their assistance and advice. We thank Scott Nichol and Bob Taylor for their thoughtful comments on an earlier draft of this manuscript.

Open Access This article is distributed under the terms of the Creative Commons Attribution 4.0 International License (http://creativecommons.org/ licenses/by/4.0/), which permits unrestricted use, distribution, and reproduction in any medium, provided you give appropriate credit to the original author(s) and the source, provide a link to the Creative Commons license, and indicate if changes were made.

\section{References}

Aadachi R. 1954. On a proof of fundamental formula concerning refraction method of geophysical prospecting and some remarks. Kumamoto Journal of Science Series A: 18-23.

Annan A.P. 2009. Ground penetrating radar: Theory and applications. In Electromagnetic principles of ground penetrating radar, ed. H.M. Jol, 3-40. New York: Elsevier Science.

Bird M. 1984. A new 1500-acre provincial park will begin in July. Halifax: Chronicle Herald-Mail Star (26 May 1984).

Blott S.J., and K. Pye. 2001. GRADISTAT: A grain size distribution and statistics package for the analysis of unconsolidated sediments. Earth Surface Processes and Landforms 26: 1237-1248.

Boyd R. 2010. Transgressive wave-dominated coasts. In: Facies models, eds. N.P. James and R.W. Dalrymple, 265-294. St. John's: Geological Association of Canada.

Boyd R., and C. Honig. 1992. Estuarine sedimentation of the Eastern Shore of Nova Scotia. Journal of Sedimentary Petrology 62: 569583.

Boyd R., A.J. Bowen, and R.K. Hall. 1987. An evolutionary model for transgressive sedimentation on the Eastern Shore of Nova Scotia. In Glaciated coasts, eds. D.M. Fitzgerald and P.S. Rosen, 87-144. San Diego: Academic Press.

Bristow C.S., P.N. Chroston, and S.D. Bailey. 2000. The structure and development of foredunes on a locally prograding coast: Insights from ground-penetrating radar surveys, Norfolk, UK. Sedimentology 47: 923-944.

Brown A.C., and A. McLachlan. 2002. Sandy shore ecosystems and the threats facing them: Some predictions for the year 2025. Environmental Conservation 29: 62-77.

Burger H.R., A.F. Sheehan, and C.H. Jones. 2006. Introduction to applied geophysics: Exploring the shallow subsurface. New York: W.W. Norton and Company, Inc.

Carter R.W.G. 1988. Coastal environments: An introduction to the physical, ecological and cultural systems of coastlines. London: Academic Press.

Carter R.W.G., and J.D. Orford. 1988. Conceptual model of coarse clastic barrier formation from multiple sediment sources. Geographical Review 78: 221-239.

Carter R.W.G., J.D. Orford, D.L. Forbes, and R.B. Taylor. 1987. Gravel barriers, headlands, and lagoons: An evolutionary model. Proceedings, Coastal Sediments '87, New Orleans, 1776-1792. New York: American Society of Civil Engineers.

Carter R.W.G., D.L. Forbes, S.C. Jennings, J.D. Orford, J. Shaw, and R.B. Taylor. 1989. Barrier and lagoon coast evolution under differing relative sea-level regimes: Examples from Ireland and Nova Scotia. Marine Geology 88: 221-242.

Carter R.W.G., J.D. Orford, D.L. Forbes, and R.B. Taylor. 1990. Morphosedimentary development of drumlin-flank barriers with rapidly rising sea level, Story Head, Nova Scotia. Sedimentary Geology 69: 117-138.
Carter R.W.G., J.D. Orford, S.C. Jennings, and J. Shaw. 1992. Recent evolution of a paraglacial estuary under conditions of rapid sea-level rise: Chezzetcook Inlet, Nova Scotia. Proceedings of the Geologists' Association 103: 167-185.

Church A.E. 1865. Halifax County E-14-15. 1:11880. A.E. Church and Co. Nova Scotia Archives.

Church J.A., P.U. Clark, A. Cazenave, J.M. Gregory, S. Jevrejeva, A. Levermann, M.A. Merrifield, G.A., Milne, R.S. Nerem, P.D. Nunn, A.J. Payne, W.T. Pfeffer, D. Stammer, A.S. Unnikrishnan. 2013. Sea level change, in: Climate Change 2013: The physical science basis. Contribution of Working Group I to the Fifth Assessment Report of the Intergovernmental Panel on Climate Change, eds. T.F. Stocker, D. Qin, G.-K. Plattner, M. Tignor, S.K. Allen, J. Boschung, A. Nauels, Y. Xia, V. Bex, P.M. Midgley, 1137 1216. Cambridge and New York: Cambridge University Press.

Davidson-Arnott R.G.D. 2010. Introduction to coastal processes and geomorphology. New York: Cambridge University Press.

Degen T. 1979. The History of Lawrencetown. Published privately. Nova Scotia Archives.

Delure A. 1983. The effect of storms on sediment in Halifax Inlet, Nova Scotia. Unpublished M.Sc. thesis Department of Earth Sciences. Halifax: Dalhousie University.

Faribault E.R. 1906. Province of Nova Scotia, Halifax County, Lawrencetown Sheet, No 53. Multicoloured Geological Map 700. Ottawa: Geological Survey of Canada.

FitzGerald D.M., and S. van Heteren. 1999. Classification of paraglacial barrier systems: Coastal New England, USA. Sedimentology 46: 1083-1108.

Folk R., and W.C. Ward. 1957. Brazos River bar: A study in the significance of grain size parameters. Journal of Sedimentary Petrology 27: 3-26.

Forbes D.L. 2005. Paraglacial coasts. In Encyclopedia of coastal science, ed. M.L. Schwartz, 760-762. Dordrecht: Springer.

Forbes D.L. 2011. Glaciated coasts. In Estuarine and coastal geology and geomorphology, eds. J.D. Hansom, and B. Flemming. In Treatise on estuarine and coastal science, series ed. E. Wolanski and D. McClusky, 3: 223-243. London, Waltham and San Diego: Academic Press.

Forbes D.L., and J.P.M. Syvitski. 1994. Paraglacial coasts. In Coastal evolution: Late Quaternary shoreline morphodynamics, eds. R.W.G. Carter, and C.D. Woodroffe, 373-424. Cambridge: Cambridge University Press.

Forbes D.L., and R.B. Taylor. 1987. Coarse-grained beach sedimentation under paraglacial conditions, Canadian Atlantic coast. In Glaciated coasts, eds. D.M. Fitzgerald and P.S. Rosen, 51-86. San Diego: Academic Press.

Forbes D.L., R. Boyd, and J. Shaw. 1991a. Late Quaternary sedimentation and sea-level changes on the inner Scotian Shelf. Continental Shelf Research 11: 155-1179.

Forbes D.L., G.K. Manson, J. Charles, K.R. Thompson, and R.B. Taylor. 2009. Halifax Harbour extreme water levels in the context of climate change: Scenarios for a 100-year planning horizon. Open File 6346. Ottawa: Geological Survey of Canada.

Forbes D.L., J.D. Orford, R.W.G. Carter, J. Shaw, and S.C. Jennings. 1995b. Morphodynamic evolution, self-organisation, and instability of coarse-clastic barriers on paraglacial coasts. Marine Geology 126: 63-85.

Forbes D.L., J.D. Orford, R.B. Taylor, and J. Shaw. 1997. Interdecadal variation in shoreline recession on the Atlantic coast of Nova Scotia. Proceedings of the Canadian Coastal Conference 1997, Guelph, 360-374. Ottawa: Canadian Coastal Science and Engineering Association.

Forbes D.L., J. Shaw, and R.B. Taylor. 1995a. Differential preservation of coastal structures on paraglacial shelves: Holocene deposits of southeastern Canada. Marine Geology 124: 187-201. 
Forbes D.L., R.B. Taylor, J.D. Orford, R.W.G. Carter, and J. Shaw. 1991b. Gravel-barrier migration and overstepping. Marine Geology 97: 305-313.

Forbes D.L., R.B. Taylor, and J. Shaw. 1989. Shorelines and rising sea levels in eastern Canada. Episodes 12: 23-28.

Forbes D.L., R.B. Taylor, J. Shaw, R.W.G. Carter, and J.D. Orford. 1990. Development and stability of barrier beaches on the Atlantic coast of Nova Scotia. Proceedings of the Canadian Coastal Conference 1990, Kingston, 83-93. Ottawa: Associate Committee on Shorelines, National Research Council Canada.

Friedman G.M. 1961. Distinction between dune, beach, and river sands from their textural characteristics. Journal of Sedimentary Petrology 31: $514-529$.

Gehrels W.R., J.R. Kirby, A. Prokoph, R.M. Newnham, E.P. Achterberg, H. Evans, S. Black, and D.B. Scott. 2005. Onset of recent rapid sealevel rise in the western Atlantic Ocean. Quaternary Science Reviews 24: 2083-2100.

Gehrels W.R., G.A. Milne, J.R. Kirby, R.T. Patterson, and D.F. Belknap. 2004. Late Holocene sea-level changes and isostatic crustal movements in Atlantic Canada. Quaternary International 120: 79-89.

González-Villanueva R., S. Costas, H. Duarte, M. Pérez-Arlucea, and I. Alejo. 2011. Blowout evolution in a coastal dune: Using GPR, aerial imagery and core records. Journal of Coastal Research Special Issue 64: 278-282.

Greenwood R.O., and J.D. Orford. 2007. Factors controlling the retreat of drumlin coastal cliffs in a low energy marine environmentStrangford Lough, Northern Ireland. Journal of Coastal Research 23: 285-297.

Hales W.J. 1992. Sand dunes of Nova Scotia. Unpublished M.Sc. thesis, Department of Geography. Hamilton: McMaster University.

Hesp P. 2002. Foredunes and blowouts: Initiation, geomorphology and dynamics. Geomorphology 48: 245-268.

Himmelstoss E.A., D.M. FitzGerald, P.S. Rosen, and J.R. Allen. 2006. Bluff evolution along coastal drumlins: Boston Harbor islands, Massachusetts. Journal of Coastal Research 22: 12301240 .

Hoskin K.S. 1983. Coastal sedimentation at Lawrencetown Beach, Eastern Shore, Nova Scotia. Unpublished B.Sc. honours thesis. Halifax: Dalhousie University.

Jennings S.C., R.W.G. Carter, and J.D. Orford. 1993. Late Holocene salt marsh development under a regime of rapid relative sea-level rise: Chezzetcook Inlet, Nova Scotia. Implications for the interpretation of palaeomarsh sequences. Canadian Journal of Earth Sciences 30: 1374-1384.

King L.H. 1972. Relation of plate tectonics to the geomorphic evolution of the Canadian Atlantic Provinces. Geological Society of America Bulletin 83: 3083-3090.

Krumbein W.C., and F.J. Pettijohn. 1938. Manual of sedimentary petrography. New York: Appleton-Century-Crofts.

Martinez M.L., N.P. Psuty, and R.A. Lubke. 2008. A perspective on coastal dunes. In Coastal dunes, ecology and conservation, eds. M.L. Martinez and N.P. Psuty, 3-10. New York: Springer.

McCann S.B. 1990. An introduction to the coastal dunes of Atlantic Canada. In Proceedings of Canadian Symposium on Coastal Sand Dunes, Guelph, ed. R.G.D Davidson-Arnott, 89-107. Ottawa: Associate Committee on Shorelines, National Research Council Canada.

Natural Resources Canada (NRCan). 2011. Impact of storms [online]. www.nrcan.gc.ca/earth-sciences/natural-hazard/other-naturalhazards/storm-impact/8591. Accessed 1 Dec 2012.

Neal A. 2004. Ground-penetrating radar and its use in sedimentology: Principles, problems and progress. Earth-Science Reviews 66: 261330.

Neal A., and C.L. Roberts. 2001. Internal structure of a trough blowout, determined from migrated ground-penetrating radar profiles. Sedimentology 48: 791-810.
Nichol S.L., and R. Boyd. 1993. Morphostratigraphy and facies architecture of sandy barriers along the Eastern Shore of Nova Scotia. Marine Geology 114: 59-80.

Orford J.D., R.W.G. Carter, and S.C. Jennings. 1996. Control domains and morphological phases in gravel-dominated coastal barriers of Nova Scotia. Journal of Coastal Research 12: 589-604.

Orford J.D., R.W.G. Carter, J. McKenna, and S.C. Jennings. 1995. The relationship between the rate of mesoscale sea-level rise and the rate of retreat of swash-aligned gravel-dominated barriers. Marine Geology 124: 177-186.

Orford J.D., S.C. Jennings, and D.L. Forbes. 2000. Origin, development, reworking and breakdown of gravel-dominated coastal barriers in Atlantic Canada: Future scenarios for the British coast. In Ecology of coastal shingle, ed. J.R. Packham, 23-55. Otley: Smith-Settle.

Phillips D. 1990. The climates of Canada. Ottawa: Canadian Government Publishing Centre.

Reed D.J., R. Davidson-Arnott, and G.M.E. Perillo. 2009. Estuaries, coastal marshes, tidal flats and coastal dunes. In Geomorphology and global environmental change, eds. O. Slaymaker, T. Spencer, and C. Embleton-Hamann, 130-157. Cambridge, UK: Cambridge University Press.

Reimer P.J., E. Bard, A. Bayliss, J.W. Beck, P.G. Blackwell, C.B. Ramsey, C.E. Buck, H. Cheng, R.L. Edwards, M. Freidrich, P.M. Grootes, T.P. Guilderson, H. Haflidason, I. Hajdas, C. Hatte, T.J. Heaton, D.L. Hoffmann, A.G. Hogg, K.A. Hughen, K.F. Kaiser, B. Kromer, S.W. Manning, M. Niu, R.W. Reimer, D.A. Richards, E.M. Scott, J.R. Southon, R.A. Staff, C.S.M. Turney, and J. van der Plicht. 2013. INTCAL13 and MARINE13 radiocarbon age calibration curves 0-50000 years cal BP. Radiocarbon 55: 1869-1887.

Scott D.B. 1980. Morphological changes in an estuary: A historical and stratigraphical comparison. In The coastline of Canada, ed. S.B. McCann, 199-205. Paper 80-10. Ottawa: Geological Survey of Canada

Scott D.B., K. Brown, E.S. Collins, and F.S. Medioli. 1995. A new sealevel curve from Nova Scotia: Evidence for a rapid acceleration of sea-level rise in the late mid-Holocene. Canadian Journal of Earth Sciences 32: 2071-2080.

Sensors and Software Inc. 2006. Pulse EKKO Pro users guide. Mississauga: Sensors and Software Inc.

Shaw J., R.B. Taylor, and D.L. Forbes. 1993. Impact of Holocene transgression on the Atlantic coastline of Nova Scotia. Géographie physique et Quaternaire 47: 221-238.

Shaw J., R.B. Taylor, D.L. Forbes, M.-H. Ruz, and S. Solomon. 1998. Sensitivity of the coasts of Canada to sea-level rise. Bulletin 505. Ottawa: Geological Survey of Canada.

Stea R.R., and Y. Brown. 1989. Variation in drumlin orientation, form and stratigraphy relating to successive ice flows in southern and central Nova Scotia. Sedimentary Geology 62: 223-240.

Stea R.R., D.J.W. Piper, G.B.J. Fader, and R. Boyd. 1998. Wisconsinan glacial and sea-level history of Maritime Canada and the adjacent continental shelf: A correlation of land and sea events. Geological Society of America Bulletin 110: 821-845.

Taylor R.B., and D. Frobel. 2001. The coastline of Nova Scotia, part 3: Atlantic coast (Halifax to Cape North). Open File 4020, video. Ottawa: Geological Survey of Canada.

Taylor R.B., D.L. Forbes, D. Frobel, G.K. Manson, and J. Shaw. 2014. Coastal geoscience studies at Bedford Institute of Oceanography, 1962-2012. In Voyage of discovery: Fifty years of marine research at Canada's Bedford Institute of Oceanography, eds. D.N. Nettleship, D.C. Gordon, C.F.M. Lewis, and M.P. Latremouille, 197- 204. Dartmouth: Bedford Institute of Oceanography Oceans Association.

Taylor R.B., D.L. Forbes, D. Frobel, J. Shaw, and G. Parkes. 1997. Hurricane Hortense strikes Atlantic Nova Scotia: An examination of beach response and recovery. Open File 3503. Ottawa: Geological Survey of Canada. 
Taylor R.B., D. Frobel, D.L. Forbes, and D. Mercer. 2008. Impacts of posttropical Storm Noel (November, 2007) on the Atlantic coastline of Nova Scotia. Open File 5802. Ottawa: Geological Survey of Canada.

Taylor R.B., D. Frobel, D. Mercer, C. Fogarty, and P. MacAulay. 2013. Impacts of four storms in December 2010 on the Eastern Shore of Nova Scotia. Open File 7356. Ottawa: Geological Survey of Canada.

Taylor R.B., J. Shaw, D.L. Forbes, and D. Frobel. 1996. Field trip guidebook: Eastern Shore of Nova Scotia: Coastal response to sea-level rise and human interference. Open File 3244. Ottawa: Geological Survey of Canada.

Taylor R.B., S.L. Wittmann, M.J. Milne, and S.M. Kober. 1985. Beach morphology and coastal changes at selected sites, mainland Nova Scotia. Paper 85-12. Ottawa: Geological Survey of Canada.
Utting D.J. 2011. Surficial geology map, part of the Cole Harbour Claim reference sheet 11D/11C, Halifax County, Nova Scotia. Open File Map ME 2011-101. Halifax: Nova Scotia Department of Natural Resources.

White C.E. 2010. Stratigraphy of the Lower Paleozoic Goldenville and Halifax groups in southwestern Nova Scotia. Atlantic Geology 46, 136-154.

Widess M.B. 1973. How thin is a thin bed?. Geophysics 38: 1176-1180.

Woodroffe C.D., R.J. Nicholls, V. Burkett, and D.L. Forbes. 2014. The impact of climate change on coastal ecosystems. In Oceans and human health: Implications for society and well-being, eds. R.E. Bowen, M.H. Depledge, C.P. Carlane, and L.E. Fleming, 141-176. Chichester: Wiley. 